\title{
Typical types and formation mechanisms of haze in an Eastern Asia megacity, Shanghai
}

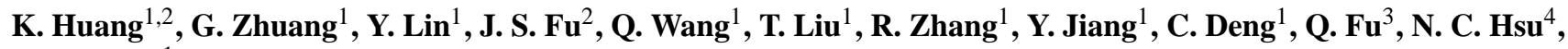 \\ and $\mathrm{B} . \mathrm{CaO}^{1}$ \\ ${ }^{1}$ Center for Atmospheric Chemistry Study, Department of Environmental Science and Engineering, Fudan University, \\ Shanghai, 200433, China \\ ${ }^{2}$ Department of Civil and Environmental Engineering, The University of Tennessee, Knoxville, TN 37996, USA \\ ${ }^{3}$ Shanghai Environmental Monitoring Center, Shanghai, 200030, China \\ ${ }^{4}$ Goddard Space Flight Center, NASA, Greenbelt, Maryland, USA
}

Correspondence to: G. Zhuang (gzhuang@ fudan.edu.cn)

Received: 13 July 2011 - Published in Atmos. Chem. Phys. Discuss.: 2 August 2011

Revised: 6 November 2011 - Accepted: 16 November 2011 - Published: 2 January 2012

\begin{abstract}
An intensive aerosol and gases campaign was performed at Shanghai in the Yangtze River Delta region over Eastern China from late March to early June 2009. This study provided a complementary picture of typical haze types and the formation mechanisms in megacities over China by using a synergy of ground-based monitoring, satellite and lidar observations. During the whole study period, several extreme low visibility periods were observed with distinct characteristics, and three typical haze types were identified, i.e. secondary inorganic pollution, dust, and biomass burning. Sulfate, nitrate and ammonium accounted for a major part of $\mathrm{PM}_{2.5}$ mass during the secondary inorganic pollution, and the good correlation between $\mathrm{SO}_{2} / \mathrm{NO}_{\mathrm{x}} / \mathrm{CO}$ and $\mathrm{PM}_{2.5}$ indicated that coal burning and vehicle emission were the major sources. Large-scale regions with high AOD (aerosol optical depths) and low Ångström exponent were detected by remote-sensing observation during the dust pollution episode, and this episode corresponded to coarse particles rich in mineral components such as $\mathrm{Al}$ and $\mathrm{Ca}$ contributing $76.8 \%$ to TSP. The relatively low $\mathrm{Ca} / \mathrm{Al}$ ratio of 0.75 along with the air mass backward trajectory analysis suggested the dust source was from Gobi Desert. Typical tracers for biomass burning from satellite observation (column $\mathrm{CO}$ and $\mathrm{HCHO}$ ) and from ground measurement (CO, particulate $\mathrm{K}^{+}, \mathrm{OC}$, and $\mathrm{EC}$ ) were greatly enhanced during the biomass burning pollution episode. The exclusive linear correlation
\end{abstract}

between $\mathrm{CO}$ and $\mathrm{PM}_{2.5}$ corroborated that organic aerosol dominated aerosol chemistry during biomass burning, and the high concentration and enrichment degree of arsenic (As) could be also partly derived from biomass burning. Aerosol optical profile observed by lidar demonstrated that aerosol was mainly constrained below the boundary layer and comprised of spheric aerosol (depolarization ratio $<5 \%$ ) during the secondary inorganic and biomass burning episodes, while thick dust layer distributed at altitudes from near surface to $1.4 \mathrm{~km}$ (average depolarization ratio $=0.122 \pm 0.023$ ) with dust accounting for $44-55 \%$ of the total aerosol extinction coefficient during the dust episode. This study portrayed a good picture of the typical haze types and proposed that identification of the complicated emission sources is important for the air quality improvement in megacities in China.

\section{Introduction}

China is now undergoing tremendous challenges of air quality impairment due to rapid industrial and transportation expansion, sharply increased demands of fossil fuel usage and increasing populations. Primary pollutant concentrations grow as a power-law function of population, and in China large emissions were concentrated in the mega-city clusters, such as Jing-Jin-Ji (Beijing-Tianjin-Hebei), the Pearl River 
Delta and Yangtze River Delta (YRD) regions (Parrish and Zhu, 2009). The YRD region, on which this study was focusing, included the biggest city in China, Shanghai, and Jiangsu and Zhejiang provinces. It has a population of over 80 million people and occupies over $21 \%$ of China's total gross domestic product (GDP).

Upon a globally decreasing trend of incoming solar radiation, sunshine duration and sky visibility (Che et al., 2005; Kaiser and Qian, 2002; Wang et al., 2009), the YRD region had experienced substantially increasing haze days since the 1990s (Chang et al., 2009; Che et al., 2007), which have been attributed to the dimming effect of aerosol. Some air quality research had been conducted in Shanghai and other areas in YRD. The emissions of black carbon and $\mathrm{NO}_{\mathrm{x}}$ in Shanghai have been measured to be 2 to 3 times higher than in Bejing and Guangzhou (2003-2005) (Chan and Yao, 2008), and the emission of $\mathrm{NO}_{\mathrm{x}}$ is predicted to increase $60-70 \%$ by 2020 due to the expansion of transportation (Chen et al., 2006). Major aerosol constituents are found to be sulfate, nitrate, ammonium (Wang et al., 2006; Yao et al., 2002; Ye et al., 2003) and organic aerosol (Feng et al., 2006, 2009; Yang et al., 2005a), concluding that fossil fuel combustion and vehicle emission are major sources of secondary components. Compared to Beijing, higher concentrations of black carbon (BC) and higher ratio of $\mathrm{BC} / \mathrm{CO}$ have been observed in Shanghai, which are attributed to larger contribution from diesel burning (diesel powered vehicles and marine vessels) (Zhou et al., 2009). Ground based sunphotometer observation at various sites in YRD show relatively high aerosol extinction to sunlight (aerosol optical depths $(\mathrm{AOD})>0.7$ ) and high fraction of fine particles (Ångström exponent $>1.0$ ) (Pan et al., 2010; Xia et al., 2007). Concentration and fraction of ultrafine $(10-100 \mathrm{~nm})$ particles in total particle counts at Taichang, YRD, are 2 to 3 times higher than those reported in the urban/suburban areas in North America and Europe (Gao et al., 2009). One research on the background site Lin'an suggested that the aerosol properties were more similar to urban areas rather than the suburban ones (Xu et al., 2002). Huang et al. (2008) found that there was a significantly decreasing trend of acid rain $\mathrm{pH}$ in Shanghai with 15-fold increased acidity during 1997-2005. Health effects of haze also have been investigated. It has been reported that cardiorespiratory diseases and carcinogenesis are partially associated with air pollution (Kan et al., 2007; Ye et al., 2000; Zhao et al., 2003) and reductions of primary $\mathrm{PM}_{2.5}$ from industrial sector and mobile sources show good health benefits in YRD (Zhou et al., 2010). It was estimated that the total economic cost of health impacts due to particulate air pollution in urban areas of Shanghai in 2001 was approximately 625.40 million US dollars, accounting for $1.03 \%$ of GDP of the city (Kan and Chen, 2004). In addition, the agriculture production was likely reduced by $2.5-9.2 \%$ due to exposure to ambient ozone (Liu et al., 2009). However, the mechanism on the formation of haze has seldom been discussed (Fu et al., 2008; Pathak et al., 2009; Zhou et al., 2009). While some intensive field campaigns have been carried out in the Pearl River Delta region and Northeastern China, i.e. PRIDE-PRD2004, PRIDE-PRD2006 (Program of Regional Integrated Experiments on Air Quality over Pearl River Delta of China 2004 and 2006; Garland et al., 2008; Zhang et al., 2008), CAREBEIJING (Regional formation processes and controlling effects of air pollution before and during the Beijing Olympics: the results of CAREBEIJING; Wang et al., 2010), and EAST-AIRE (East Asian Studies of Tropospheric Aerosols: An International Regional Experiment; Li et al., 2007), no comprehensive initiatives have been undertaken in YRD. Furthermore, the source of haze, which has also been referred to the atmospheric brown clouds (ABC), is not well disentangled due to the complicated aerosol sources in China currently.

In this study, an intensive field experiment using various techniques was targeted to determine the typical pollution types that caused the frequent occurrence of haze in Eastern China. Aerosol chemical and optical experiments were combined with remote-sensing observation to distinguish and characterize different types of haze. Comments and discussions are made to emphasize the importance of aerosol source determination, which hopefully will be beneficial for the local governments to improve air quality and mitigate climate effects.

\section{Methodology}

\subsection{Field observations}

\subsubsection{Observational site}

The observational site $\left(31.3^{\circ} \mathrm{N}, 121.5^{\circ} \mathrm{E}\right)$ in this study is on the roof ( $\sim 20 \mathrm{~m}$ high) of a teaching building on the campus of Fudan University in Yangpu district of Shanghai. Almost no high buildings are around this sampling site. This observational site is approximately $40 \mathrm{~km}$ inland from the East China Sea. The closest industrial sources are located approximately $10.5 \mathrm{~km}$ away and are primarily to the southeast and northwest (Li et al., 2011). About 1.3 million residents are living in this area (SMSB, 2011). This site could be regarded as a representative of the megacity Shanghai, standing for the mixing of residential, traffic, construction, and industrial sources (Wang et al., 2006).

\subsubsection{Automatic aerosol and gases monitoring}

The Thermo Scientific TEOM (Tapered Element Oscillating Microbalance) 1405-D monitor simultaneously measured $\mathrm{PM}_{2.5}$, PM-Coarse $\left(\mathrm{PM}_{10-2.5}\right)$ and $\mathrm{PM}_{10}$ mass concentration upon an oscillating balance. PM (particulate matter) accumulating on a filter mounted changes in the frequency of oscillation, which were related to the mass of material accumulating on the filter, were detected in quasi-real-time and converted by a microprocessor into an equivalent PM 
mass concentration every few seconds at a 10 min running average. The sampler split a $\mathrm{PM}_{10}$ sample stream into its fine $\left(\mathrm{PM}_{2.5}\right)$ and coarse $\left(\mathrm{PM}_{10-2.5}\right)$ fractions using a USEPA (US Environmental Protection Agency)-designed virtual impactor for the additional $2.5 \mu \mathrm{m}$ cutpoint. The total flow rate operated at $16.671 \mathrm{~min}^{-1}$, and two separate flow controllers maintained the coarse particle stream at $1.671 \mathrm{~min}^{-1}$ and the fine particle stream at $3.01 \mathrm{~min}^{-1}$. Another Thermo Scientific TEOM 1405 monitor was set up to measure $\mathrm{PM}_{1}$ mass concentration operating at $3.01 \mathrm{~min}^{-1}$ with a bypass flow rate of $13.671 \mathrm{~min}^{-1}$. PM concentrations were averaged and used at intervals of $1 \mathrm{hr}$ in this study. Trace gases instruments included a $43 i \mathrm{SO}_{2}$ analyzer, $42 i \mathrm{NO}-\mathrm{NO}_{2}-\mathrm{NO}_{\mathrm{x}}$ analyzer, $49 i$ $\mathrm{O}_{3}$ analyzer and $48 i \mathrm{CO}$ analyzer. The routine $\mathrm{QA} / \mathrm{QC}$ procedures included the daily zero/standard calibration, span and range check, station environmental control, staff certification, etc., according to the Technical Guideline of Automatic Stations of Ambient Air Quality in Shanghai based on the national specification HJ/T193-2005, which was developed following the technical guidance established by the US EPA (USEPA, 1998). The multi-point calibrations were applied weekly upon initial installation of the instruments. And the two-point calibrations were applied on a daily basis.

\subsubsection{Manual sampling}

Aerosol samples of TSP and $\mathrm{PM}_{2.5}$ were collected on Whatman 41 filters (Whatman Inc., Maidstone, UK) using medium-volume samplers manufactured by Beijing Geological Instrument-Dickel Co., Ltd. (model: TSP/PM $10 / \mathrm{PM}_{2.5}$ 2; flow rate: $77.591 \mathrm{~min}^{-1}$ ). Aerosol samples of $\mathrm{PM}_{10}$ were collected on Whatman quartz microfiber filters $(\mathrm{QM} / \mathrm{A}$, $18.5 \mathrm{~cm} \times 23.7 \mathrm{~cm}$ ) using the high-volume sampler (Thermo, flow rate: $\left.1.00 \mathrm{~m}^{-3} \mathrm{~min}^{-1}\right)$. All the samplers were co-located with the online instruments on the roof $(\sim 30 \mathrm{~m})$ of the 4 th Teaching Building at Fudan University, Shanghai. The duration time of sampling was generally $24 \mathrm{~h}$. More samples with shorter duration time were collected during the heavy haze days. The filters before and after sampling were weighed using an analytical balance (Model: Sartorius 2004MP) with a reading precision $10 \mathrm{mg}$ after stabilizing in constant temperature $\left(20 \pm 1{ }^{\circ} \mathrm{C}\right)$ and humidity $(40 \pm 1 \%)$. All the procedures were strictly quality controlled to avoid the possible contamination of samples.

\subsubsection{Lidar observation}

A dual-wavelength depolarization lidar (Model: L2S-SM II) developed by the National Institute for Environmental Studies (NIES) was operated in this field campaign. The lidar could measure backscattering coefficients and the depolarization ratio at wavelength of $532 \mathrm{~nm}$. The Lidar employed a flash lamp pumped Nd:YAG laser with a second harmonics generator. The laser beam was vertically oriented to the sky after collimated with a beam expander. Transmit- ted laser energy was typically $20 \mathrm{~mJ}$ per pulse at $1064 \mathrm{~nm}$ and $30 \mathrm{~mJ}$ per pulse at $532 \mathrm{~nm}$. The pulse repetition rate was $10 \mathrm{~Hz}$. The scattered light was received with a $20 \mathrm{~cm}$ Schmidt Cassegrain type telescope collimated and directed to the dichroic mirror. The polarization components were detected with two photomultiplier tubes (PMTs). Detected signals were recorded with a transient recorder (digital oscilloscope), averaged and transferred to the data acquisition computer for the web interface. The lidar continuously operated with $15 \mathrm{~min}$ intervals and $30 \mathrm{~m}$ height resolution by setting a boundary condition at $3 \mathrm{~km}$. The Fernald inversion method (Fernald, 1984) was applied to deriving the extinction coefficient with lidar ratio (extinction-to-backscatter ratio) set to $50 \mathrm{sr}$ (Liu et al., 2002) in inversion process.

\subsection{Chemical analysis}

\subsubsection{Ion analysis}

One-fourth of each sample and blank filter was extracted ultrasonically by $10 \mathrm{ml}$ deionized water $\left(18 \mathrm{M} \Omega \mathrm{cm}^{-1}\right)$. Eleven inorganic ions $\left(\mathrm{SO}_{4}^{2-}, \mathrm{NO}_{3}^{-}, \mathrm{F}^{-}, \mathrm{Cl}^{-}, \mathrm{NO}_{2}^{-}, \mathrm{PO}_{4}^{3-}, \mathrm{NH}_{4}^{+}\right.$, $\mathrm{Na}^{+}, \mathrm{K}^{+}, \mathrm{Ca}^{2+}, \mathrm{Mg}^{2+}$ ) and four organic acids (formic, acetic, oxalic, and methylsulfonic acid "MSA") were analyzed by Ion Chromatography (ICS 3000, Dionex), which consisted of a separation column (Dionex Ionpac AS 11), a guard column (Dionex Ionpac AG 11), a self-regenerating suppressed conductivity detector (Dionex Ionpac ED50) and a gradient pump (Dionex Ionpac GP50). The detail procedures are given elsewhere (Yuan et al., 2003).

\subsubsection{Element analysis}

Half of each sample and blank filter was digested at $170{ }^{\circ} \mathrm{C}$ for $4 \mathrm{~h}$ in high-pressure Teflon digestion vessel with $3 \mathrm{ml}$ concentrated $\mathrm{HNO}_{3}, 1 \mathrm{ml}$ concentrated $\mathrm{HCl}$, and $1 \mathrm{ml}$ concentrated HF. After cooling, the solutions were dried and then diluted to $10 \mathrm{ml}$ with distilled deionized water. A total 24 elements (Al, Fe, Mn, Mg, Mo, Ti, Sc, Na, Ba, Sr, Sb, Ca, $\mathrm{Co}, \mathrm{Ni}, \mathrm{Cu}, \mathrm{Ge}, \mathrm{Pb}, \mathrm{P}, \mathrm{K}, \mathrm{Zn}, \mathrm{Cd}, \mathrm{V}, \mathrm{S}$, and As) were measured by using an inductively coupled plasma atomic emission spectroscopy (ICP-OES; SPECTRO, Germany). The detailed analytical procedures are given elsewhere (Sun et al., 2004; Zhuang et al., 2001).

\subsubsection{Carbonaceous aerosol analysis}

Quartz filters were pre-heated at $500^{\circ} \mathrm{C}$ for $5 \mathrm{~h}$ before using and the samples were analyzed for OC/EC using Thermal/Optical Carbon Analyzer (DRI Model 2001). The IMPROVE thermal/optical reflectance (TOR) protocol (Chow and Watson, 2002) was used for the carbon analysis. The eight fractions (OC1, OC2, OC3, OC4 at 120, 250, 450 and $550^{\circ} \mathrm{C}$, respectively, in a helium atmosphere; $\mathrm{EC} 1, \mathrm{EC} 2$, $\mathrm{EC} 3$ at 550,700 and $800{ }^{\circ} \mathrm{C}$, respectively, in the $98 \%$ helium $/ 2 \%$ oxygen atmosphere) and OPC (optically detected 
pyrolized carbon) were measured separately. The IMPROVE protocol defined $\mathrm{OC}$ as $\mathrm{OC} 1+\mathrm{OC} 2+\mathrm{OC} 3+\mathrm{OC} 4+\mathrm{OPC}$ and $\mathrm{EC}$ as $\mathrm{EC} 1+\mathrm{EC} 2+\mathrm{EC} 3-\mathrm{OPC}$.

\subsection{Satellite observation}

In this study, a number of satellite sensors were used to provide spatial information of aerosol and trace gases. The MODIS instrument (Moderate-resolution Imaging Spectroradiometer) provided a large regional view of aerosol distributions with a resolution of $10 \times 10 \mathrm{~km}$. Operational aerosol optical depths were reported at $0.55 \mu \mathrm{m}$ by NASA (Chu et al., 2003; Kaufman et al., 1997). The total carbon monoxide column concentration retrieved from Atmospheric Infrared Sounder (AIRS) on board NASA's Aqua satellite were used to observe large scale transport from biomass burning sources (McMillan et al., 2005). Launched in 2004, the Dutch-Finnish built Ozone Monitoring Instrument (OMI) aboard NASA's EOS Aura satellite provided daily global coverage with a spatial resolution of $13 \mathrm{~km} \times 24 \mathrm{~km}$ at nadir (Levelt et al., 2006), and the total formaldehyde column concentration was used to study the signals of possible biomass burning source. Detailed description about the OMI instrument can be found elsewhere (Kurosu et al., 2004).

\section{Results and discussion}

\subsection{Identification of three pollution episodes}

An intensive aerosol characterization campaign was carried out in the Yangtze River Delta region with focus on Shanghai in 2009, which aimed at gaining insights into the formation mechanisms of haze in Eastern China. The study period included two time spans of 30 March-16 May and 28 May-3 June; the absent interval between the two spans was due to malfunction and maintenance of some instruments. Haze was usually defined as an atmospheric phenomenon, where dust, smoke and other pollutant particles reduced the visibility of the sky. Here, we calculated the visibility following the Koschmieder formula $L_{\mathrm{V}}=3.912 / \sigma_{\text {ext }}$, where $L_{\mathrm{V}}(\mathrm{km})$ was the visibility and the total extinction coefficient $\sigma_{\text {ext }}\left(\mathrm{km}^{-1}\right)$ was accounted by the scattering and absorption from particles and gases. The method for calculating $\sigma_{\text {ext }}$ is described in Appendix A. Figure 1b shows the calculated hourly visibility and the recorded visibility at Pudong, which was about $32 \mathrm{~km}$ from the observational site for this study (an upper limit of $L_{\mathrm{V}}=10 \mathrm{~km}$ was recorded at the meteorological station of Pudong). As shown in the figure, the visibility measured by two different approaches had relatively good time-series consistency, especially during the low visibility periods, which suggested that visibilities estimated from aerosol extinction profile and pollutant gas were reasonable and could be used for further analysis.

Figure 1c shows the temporal variation of PM mass concentration levels at three different sizes, i.e. $\mathrm{PM}_{1}, \mathrm{PM}_{2.5}$ and $\mathrm{PM}_{10}$. Based on the visibility, PM mass concentration levels and mass fraction of fine particles $\left(\mathrm{PM}_{2.5} / \mathrm{PM}_{10}\right)$, we sorted out three typical pollution episodes. The first pollution episode (PE1) occurred from 4-10 April, during which the mean visibility was as low as $3.5 \mathrm{~km}$. The average concentrations of $\mathrm{PM}_{1}, \mathrm{PM}_{2.5}$, and $\mathrm{PM}_{10}$ were $60.9 \pm 14.0$, $63.6 \pm 16.4$, and $120.1 \pm 40.7 \mu \mathrm{g} \mathrm{m}^{-3}$, respectively. The average ratio of $\mathrm{PM}_{2.5} / \mathrm{PM}_{10}$ was $0.54 \pm 0.09$, indicating both fine and coarse particles could be important in the formation of pollution. The mass ratio of $\mathrm{PM}_{1} / \mathrm{PM}_{2.5}$ ranged from 0.90 to 0.99 , suggesting that the mass of $\mathrm{PM}_{2.5}$ was mainly dominated by smaller particles, i.e. $\mathrm{PM}_{1}$. Time series of pollutant gases, i.e. $\mathrm{SO}_{2}, \mathrm{NO}_{\mathrm{x}}$ and $\mathrm{CO}$, showed their significant enhancements during this period (Fig. 2); enhanced industrial and traffic emissions were probably responsible for this and the pollution during this period was probably caused by the local photochemical process. The detailed analysis on pollutant gases is discussed in Sect. 3.5. Figure 1a shows the hourly surface meteorological parameters, including wind speed, wind direction, relatively humidity $(\mathrm{RH})$, dew point and atmospheric pressure. A surface high pressure system persisted during PE1 locally. As also illustrated in the weather map (Fig. S1), the center of surface high pressure strengthened in the major areas of Eastern and Central China, leading to the stagnant dispersion conditions and finally moved out to the East China Sea at the end of this episode. During PE1, the local air was under a low pressure system, turning from a high one several days earlier. Winds blew from various directions and the wind speeds were relatively low and even stagnant sometimes, which were not favorable for the dispersion of pollution. There was an obvious decrease of relative humidity $(\mathrm{RH})$ during PE1. A cold front from inland China probably contributed to the high pollution of PE1. To study the aerosol transport characteristics, air mass backward trajectories were computed using the NOAA Hybrid Single-Particle Lagrangian Trajectory (HYSPLIT) model (R. Draxler and G. Rolph, HYSPLIT (HYbrid Single - Particle Lagrangian Integrated Trajectory) Model, 2003, http://www.arl.noaa.gov/ready/hysplit4.html) with meteorological data provided by the Global Data Assimilation System (GDAS). Three-day backward trajectories at the end point of Shanghai during PE1 showed that air flows derived from various directions and traveled relatively short distances, consistent with the surface meteorological measurements. Additionally, the daily average mixing layer was almost below $500 \mathrm{~m}$ (Fig. 3a). This typical stagnant synoptic meteorological condition was especially unfavorable for the dispersion of particles and gases, and beneficial for the formation of haze pollution.

The second pollution episode (PE2) occurred on 25 April and lasted a short duration. The daily concentrations of $\mathrm{PM}_{1}, \mathrm{PM}_{2.5}$, and $\mathrm{PM}_{10}$ were 26.3, 53.0, and $174.5 \mu \mathrm{g} \mathrm{m}^{-3}$, respectively. And the ratio of $\mathrm{PM}_{2.5} / \mathrm{PM}_{10}$ reached the lowest value of 0.35 over the whole study period, indicating the characteristic of coarse particle pollution. Surface 


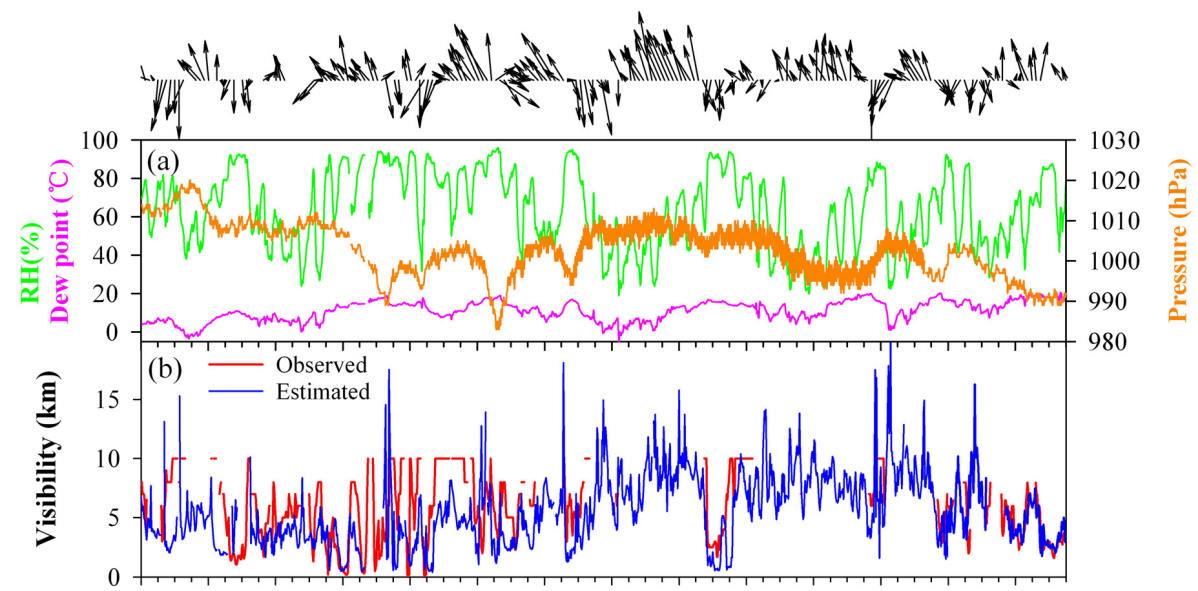

03-30 04-03 04-07 04-11 04-15 04-19 04-23 04-27 05-01 05-05 05-09 05-13 05-28 06-01

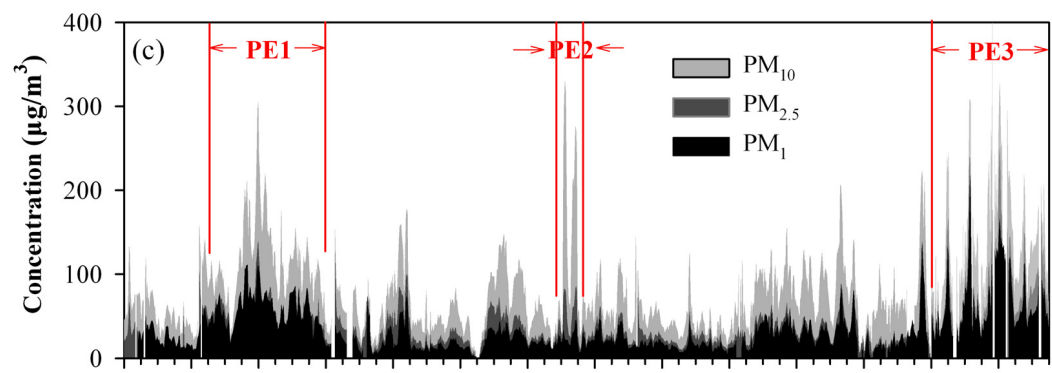

03-30 04-03 04-07 04-11 04-15 04-19 04-23 04-27 05-01 05-05 05-09 05-13 05-28 06-01

Date

Fig. 1. (a) Time-series of the meteorological parameters during the study period (30 March-16 May and 28 May-3 June) in 2009 over Shanghai, including wind speed $\left(\mathrm{m} \mathrm{s}^{-1}\right)$, wind direction, relatively humidity $(\%)$, dew point $\left({ }^{\circ} \mathrm{C}\right)$ and atmospheric pressure (hPa). (b) Timeseries of the calculated and observed hourly visibility $(\mathrm{km})$ during the same study period as above. The observed visibility recorded at Pudong had an upper limit of $10 \mathrm{~km}$ (Data source: National Climatic Data Center (NCDC)). The method of calculating the visibility was described in Appendix A. (c) Time-series of the hourly particulate concentrations of $\mathrm{PM}_{1}, \mathrm{PM}_{2.5}$ and $\mathrm{PM}_{10}\left(\mu \mathrm{g} \mathrm{m}{ }^{-3}\right.$ ), three pollution episodes were highlighted in the figure.

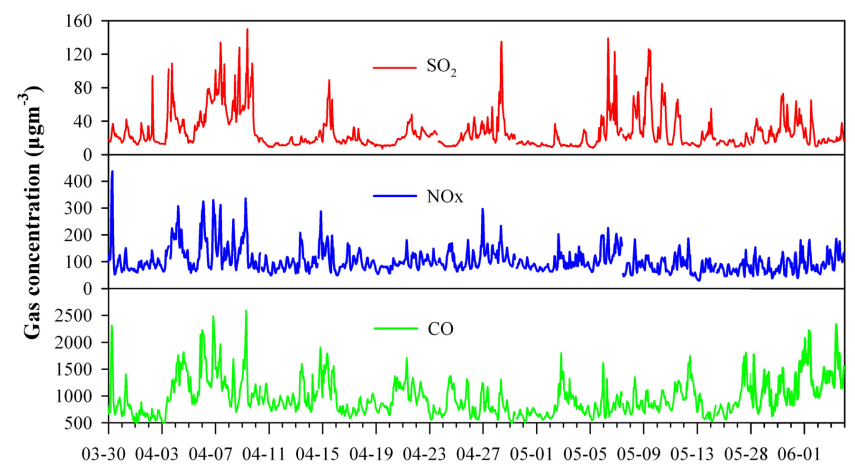

Fig. 2. Time-series of the hourly gaseous concentrations of $\mathrm{SO}_{2}$, $\mathrm{NO}_{\mathrm{x}}$ and $\mathrm{CO}$, all units are in $\mu \mathrm{g} \mathrm{m}^{-3}$.

meteorology showed a dominant northwest wind (Fig. 1a) and air backward trajectories starting at three altitudes of 500, 1000 and $3000 \mathrm{~m}$, which all flowed from Northern
China and passed over the Gobi Desert in Mongolia and Inner-Mongolia (Fig. 3b). The average wind speed reached as high as $7.5 \mathrm{~ms}^{-1}$ in Shanghai with gust speeds over $10 \mathrm{~m} \mathrm{~s}^{-1}$. Relative humidity and dew points both had abrupt decreases, indicating the advent of a cold front. Additionally, the intraday average mixing height was about $1000 \mathrm{~m}$, much more elevated than PE1. Thus, all the evidence above indicated that this coarse particle pollution was probably caused by the entrainment of dust aerosol from the desert in Mongolia and Inner-Mongolia via the long-range transport. Figure 4 depicts the regional distribution pattern of $\mathrm{PM}_{10}$ concentration during 24-26 April in Northern and Eastern China. On 24 April, high pollution $\left(\mathrm{PM}_{10}>300 \mu \mathrm{g} \mathrm{m}^{-3}\right)$ occurred in Northern China, mainly in Inner-Mongolia and Shanxi province, while the Eastern and Southern China was virtually dust-free (Fig. 4a). On the next day, abundant particles moved to major areas of central China and stretched to the eastern coastal regions (Fig. 4b). As for Shanghai, our monitoring station observed that the dust entrainment actually had the most significant impacts on local air 

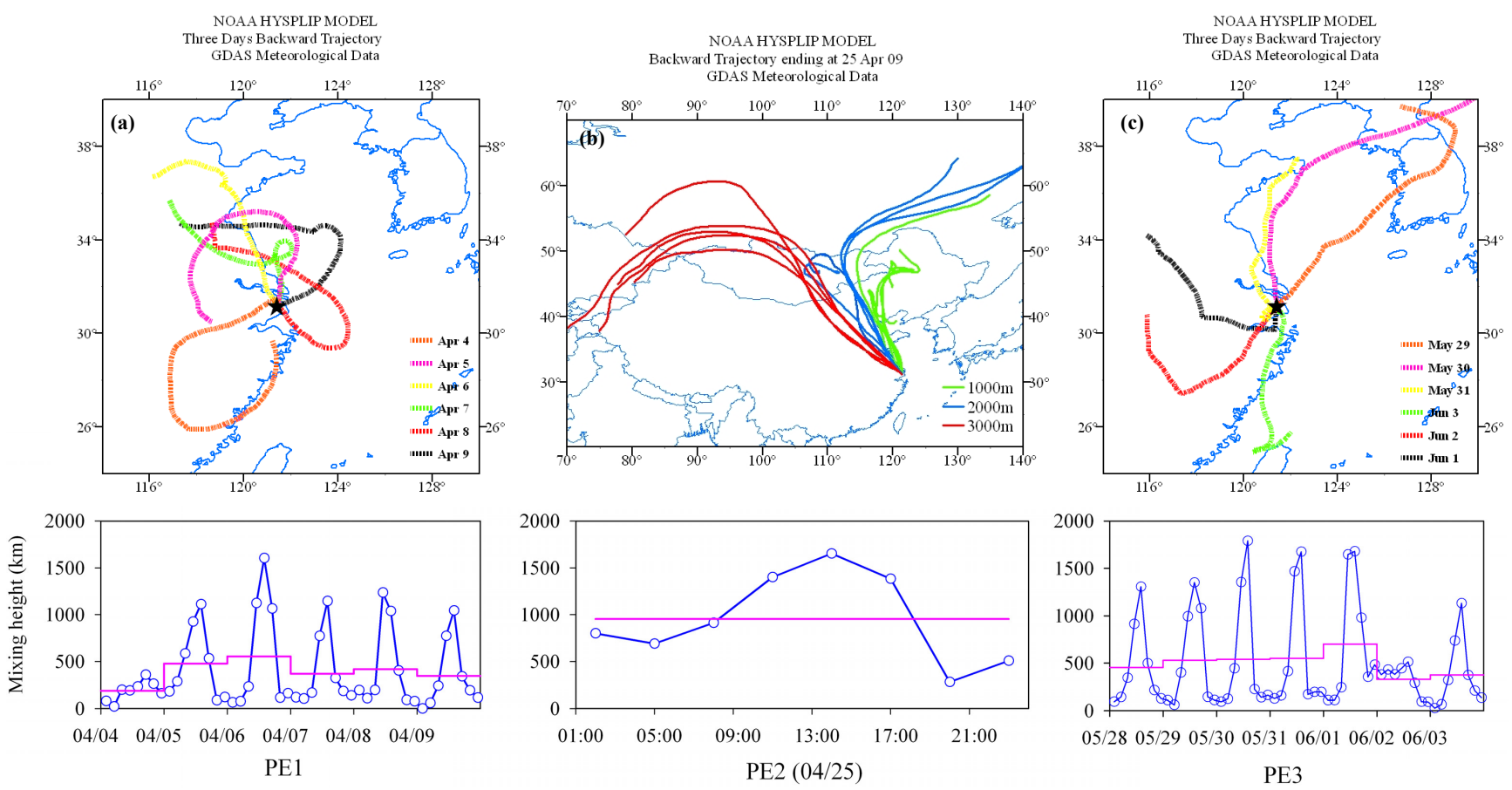

Fig. 3. Three days air mass backward trajectory at Shanghai computed by the NOAA Hybrid Single-Particle Lagrangian Trajectory (HYSPLIT) model during (a) PE1, (b) PE2, and (c) PE3, respectively. The starting altitude during PE1 and PE3 was $500 \mathrm{~m}$ and three altitudes of 500, 1000 and $1500 \mathrm{~m}$ were computed during PE2. The mixing heights during the three episodes were computed using the NCEP Global Data Assimilation System (GDAS) model (http://ready.arl.noaa.gov/READYamet.php) and shown below the trajectory panel (blue dots denoted the $3 \mathrm{~h}$ average mixing height and the pink horizontal step lines denoted the daily average mixing height).

quality during two periods, i.e. from 01:30 to 08:00 LST (Local Standard Time) and 17:00 to 23:00 LST. The average $\mathrm{PM}_{10}$ concentration reached 258 and $236 \mu \mathrm{g} \mathrm{m}^{-3}$, respectively, while the concentrations of fine particles and pollutant gases stayed at low values (Figs. $1 \mathrm{~b}$ and 2), which was due to the dilution effect of dust on local pollutants. Till 26 April, the PM concentrations in Northern China had sharply declined and the dust continued to travel southwestward along the east coast, which exerted a moderate influence on air quality of Southern China (Fig. 4c). In Shanghai, there was a significant decreased $\mathrm{PM}_{10}$ concentration and an increased $\mathrm{PM}_{2.5} / \mathrm{PM}_{10}$ ratio over 0.50 , indicating the re-dominance of fine particles after the pass of dust.

The third pollution episode (PE3) occurred from 28 May to 3 June. The average concentrations of $\mathrm{PM}_{1}, \mathrm{PM}_{2.5}$, and $\mathrm{PM}_{10}$ were $67.8 \pm 37.6,84.0 \pm 48.4$ and $135.6 \pm 71.4 \mu \mathrm{g} \mathrm{m}^{-3}$, respectively, with the average $\mathrm{PM}_{2.5} / \mathrm{PM}_{10}$ ratio of $0.65 \pm 0.04$. Fine particle concentration and its mass contribution to the total particles were both the highest among all three pollution episodes. Notwithstanding, the concentration of pollutant gases were not as high as PE1 except $\mathrm{CO}, \mathrm{SO}_{2}$ was at a moderate level and $\mathrm{NO}_{\mathrm{x}}$ was relatively low (Fig. 2). Since the relative low concentration of pollutant gases during PE3 was different from the high concentrations of pollutant gases during PE1, the for- mation mechanism of the PE3 pollution should be different from that of PE1. As shown in the weather map (Fig. S2), Shanghai was at the edge of the high pressure system during this episode. Compared to PE1, the inversion during PE3 should be weaker. The meteorological conditions during this period were similar to PE1, i.e. slow transport of air flows (Fig. 1a) and relatively low mixing layer (Fig. 3c), which also suggested the stagnant atmospheric condition during PE3.

As demonstrated above, the analysis of PM, pollutant gases and meteorological parameters has already shed light on the pollution types of three different episodes. In the following sections, more information from the aerosol optical and chemical properties will be discussed.

\subsubsection{Regional characteristics and possible sources via remote sensing observation}

The satellite remote sensing delivers reliable information about the spatial distribution, transport and possible source of airborne pollutants. Figure 5 shows the signals of typical pollutants observed by satellite sensors during the three episodes, respectively. During PE1, zones of high aerosol optical depths (AOD) at the wavelength of $550 \mathrm{~nm}$ retrieved from MODIS were mainly concentrated in Jing-JinJi (Beijing-Tianjin-Hebei), Shandong, Anhui, Henan, Hubei 

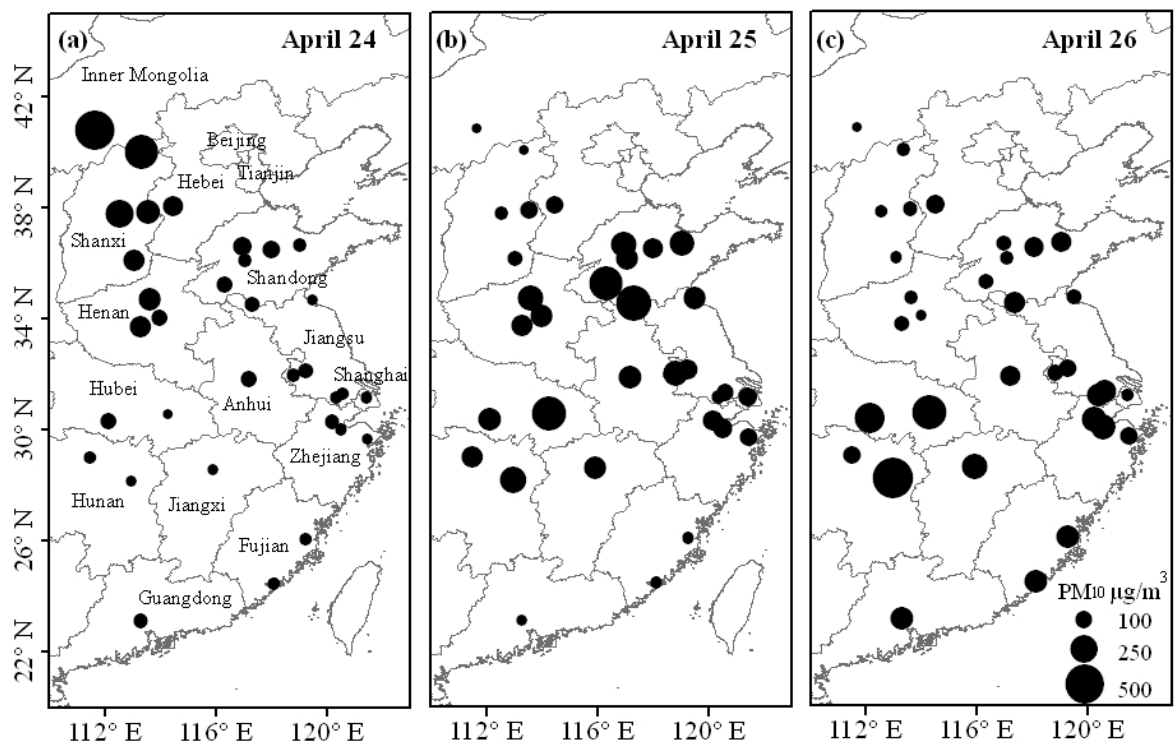

Fig. 4. Regional distribution of $\mathrm{PM}_{10}$ concentration $\left(\mu \mathrm{g} \mathrm{m}^{-3}\right)$ during 24-26 April (Data source: Ministry of Environment Protection of the PRC, http://www.zhb.gov.cn/).

provinves, and the Yangtze River Delta region, including northern part of Zhejiang, Jiangsu provinces and Shanghai (Fig. 5a). The average AOD value over Shanghai reached an extremely high value of over 1.2 , indicating strong aerosol extinction to sunlight in the atmosphere. Figure $5 \mathrm{~b}$ shows the spatial distribution of Ångström exponent at the wavelength range from 470 to $670 \mathrm{~nm}$. Ångström exponent is an indicator of the aerosol size distribution, the larger value indicates the smaller particle size, and vice versa. As the MODIS-reported Ångström exponent was only moderately well validated by using the ground-based AERONET measurements, it may be insufficient for quantitative analysis (Levy et al., 2010). Thus, it was used for the qualitative comparison among the episodes in the study. The spatial pattern of Ångström exponent did not resemble that of AOD. In some regions with moderate AOD values, such as southern parts of Zhejiang province and major parts of central China, the Ångström exponents ranged from 1.3 to 1.5 , indicating these regions were mainly dominated by fine particles. While in the high AOD regions specified above, the Ångström exponents ranged from 0.8 to 1.2 . The relative low Ångström exponents in these high AOD regions suggested there was non-negligible contribution of coarse particles during PE1. This conclusion is consistent with the moderate $\mathrm{PM}_{2.5} / \mathrm{PM}_{10}$ ratio measured by the ground monitoring results in Sect. 3.1. As shown in Fig. 5b, there was a belt of relatively low Ångström exponent regions extending from the Bohai Bay and the Shandong Peninsular to the Yangtze River Delta region along the east coast. The spatial continuity of Ångström exponent probably indicates that the Yangtze River Delta could have been more or less influenced by the dust flow from Northern China. As PE1 was in the spring season when the occurrence of floating dust was frequent and ubiquitous, the downstream regions were probably influenced by the transport of dust aerosol to some extent.

During PE2, high AOD values were observed in most parts of the study domain, which was similar to PE1 to a certain extent, especially in central and Eastern China with AOD exceeding 1.2 (Fig. 5c). However, Ångström exponents were much lower than PE1. It ranged from 0.5 to 0.6 (Fig. 5d), indicating the existence of considerable coarse particles, which was consistent with ground measurements. There were almost no regional gradients of Ångström exponents, suggesting this episode was characteristic of large-scale influences. The remote sensing analysis confirmed that PE2 was impacted by the long-range transport of dust. The dust storm had spread over almost the whole North China Plain and Eastern China as shown in Fig. 5d.

During PE3, large quantities of fire spots retrieved from MODIS were observed in the study domain (denoted by black dots in Fig. 5e-g), and they were mainly located in the conjunction of western Shanghai and southern Jiangsu province, major parts of Jiangsu, Northern Zhejiang, Northern Anhui Province and eastern parts of Shandong Province. The total column concentration of carbon monoxide (CO) retrieved from the Atmospheric Infrared Sounder (AIRS) obviously enhanced over the fire spots areas (Fig. 5e). Various studies have used $\mathrm{CO}$ as tracer for biomass burning in aircraft measurement (Boian and Kirchhoff, 2004), satellite observation (Choi and Chang, 2006; Mari et al., 2008) and other measurements (Kato et al., 1999; Kato et al., 2002). The column concentration of $\mathrm{CO}$ over the intense burning areas reached $2.5 \sim 3.0 \times 10^{18}$ molecules $\mathrm{cm}^{-2}$ as shown in the figure, evidently distinguished from areas free of biomass 

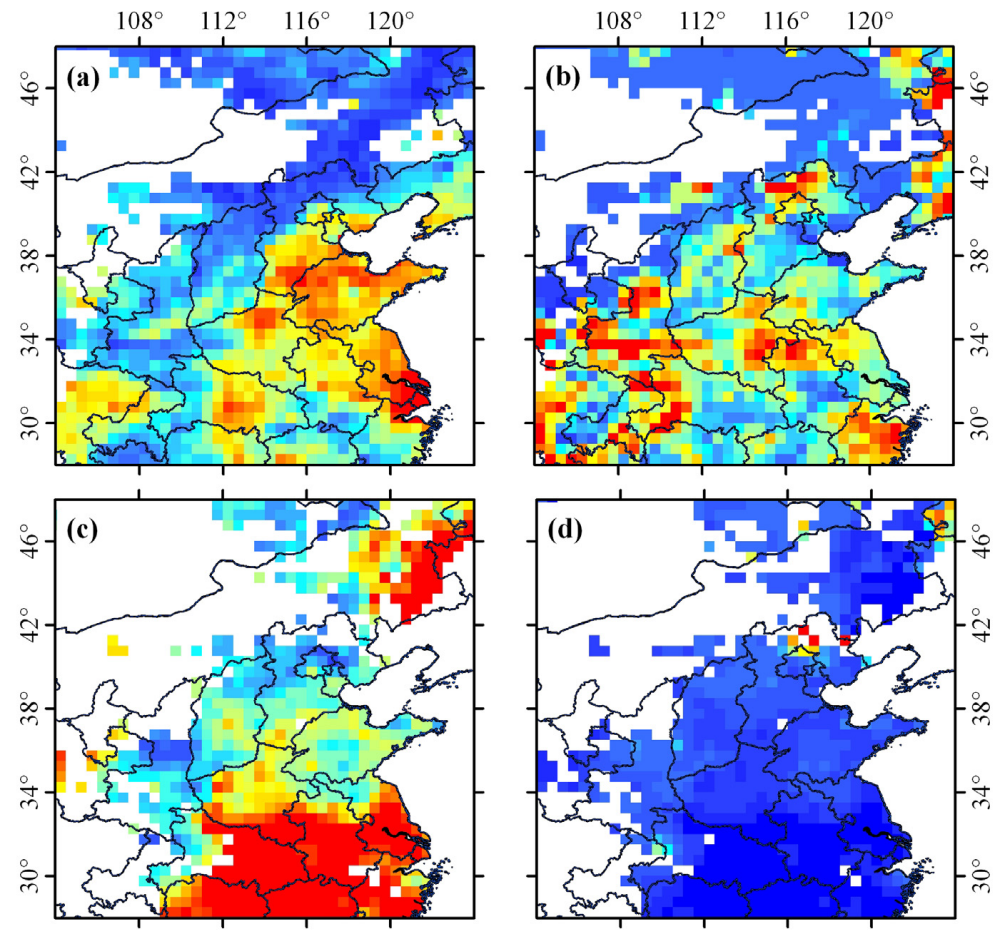

Aerosol Optical Depth

Angstrom Exponent

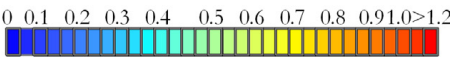
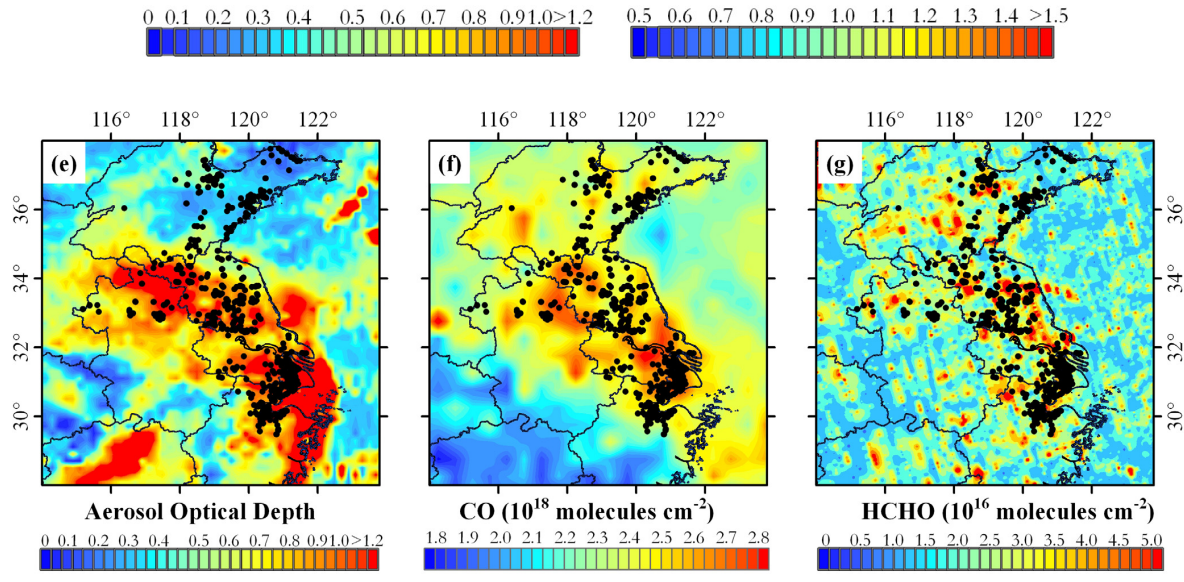

Fig. 5. The regional distribution of (a) aerosol optical depth $(550 \mathrm{~nm})$, and (b) Ångström exponent (470-670 nm) retrieved from MODIS during PE1; (c) aerosol optical depth, and (d) Ångström exponent during PE2; (e) aerosol optical depth, (f) total CO column concentration (molecules $\mathrm{cm}^{-2}$ ) retrieved from AIRS, and (g) total formaldehyde column concentration (molecules $\mathrm{cm}^{-2}$ ) retrieved from OMI during PE3, respectively. Total fire spots (black dots in the figure) retrieved from MODIS were plotted for PE3.

burning and close to the levels when biomass burning occurred in Northeastern China (Choi and Chang, 2006). Accordingly, the Ozone Monitoring Instrument (OMI) also detected high formaldehyde (HCHO) columns over the intense burning areas (Fig. 5f). HCHO is a primary emission product from biomass burning, which is an intermediate product from the oxidation of hydrocarbons. This was a good indicator of the local photochemical source as it only had a lifetime of a few hours. HCHO columns over the hotspot regions were greater than $3.0 \times 10^{16}$ molecules $\mathrm{cm}^{-2}$, more than a factor of 2-4 larger than the areas free of fires. Spatial correlations between $\mathrm{CO}$ and $\mathrm{HCHO}$ with the numbers of fire spots showed moderate correlation $(R \sim 0.49)$ (not shown in figure). Thus, the enhancement of $\mathrm{CO}$ and $\mathrm{HCHO}$ in the accumulated fire spot regions indicated that the pollution during PE3 was caused by biomass burning. The biomass emission resulted in high AOD values where large fire spots occurred, with the highest AOD up to about 2.0 in the Yangtze River Delta region. However, compared to the spatial distribution of $\mathrm{CO}$ and $\mathrm{HCHO}$, the high AOD levels did not 
always coincide with the fire regions. For example, there were no fire spots observed in Jiangxi province with low $\mathrm{CO}$ concentrations, but a high AOD region was found there. As for Shandong Province, the regions with great fire spots, high $\mathrm{CO}$, and $\mathrm{HCHO}$ concentrations were at the relatively low AOD level. This suggested that $\mathrm{CO}$ and $\mathrm{HCHO}$ were more sensitive to biomass burning than AOD as AOD represented the overall extinction of various emission sources to light rather than the single source from biomass burning. The relatively low AOD over the Shandong Peninsula could have been due to the cleanup effect of the sea breezes as it was close to the sea. Anyway, the relatively good consistency between the observed satellite signals (e.g. carbon monoxide, formaldehyde and aerosol optical depth) over Eastern China and the fire hotspots clearly indicated that biomass burning should be the major cause of heavy haze during this period. Every year during May, June and October in Eastern China, crop residues after harvest were either directly returned to agriculture fields as fertilizer, burned in the field, or used as biofuels. It has been previously reported that biomass burning usually occurs during the transition period from spring to summer (Wang et al., 2002) and in autumn (Xu et al., 2002), which is due to the burning of post-harvest straws.

In this section, the remote sensing analysis has given some insights into the different characteristics of three pollution episodes, including possible sources and transport pathways and provided some consistent results to our ground measurements. However, there were large uncertainties due to the satellite detection limit of the small fire size of the field crop residue burning that could therefore possibly be missed by satellite observations (Chang and Song, 2010; Yan et al., 2006). And satellites could not capture all fire events occurring during this study period, because fires hidden under clouds can not be easily detected. Additionally, satellite overpass also brings about the missed detection of hotspots.

\subsection{Aerosol chemistry under different atmospheric conditions}

The results of aerosol chemical analysis have been demonstrated in this section to further identify the different types of hazes as envisioned by the above discussion. Figure 6 shows the temporal variations of some typical aerosol components during the whole study period. Time series of three major secondary inorganic species in $\mathrm{PM}_{2.5}$, i.e. $\mathrm{SO}_{4}^{2-}, \mathrm{NO}_{3}^{-}$, and $\mathrm{NH}_{4}^{+}$are presented in Fig. 6a. Obviously, the total concentrations of the three species exhibited the highest levels during PE1 with an average concentration of $48.86 \pm 5.01 \mu \mathrm{g} \mathrm{m}^{-3}$, which accounted for an average of $77 \%$ to $\mathrm{PM}_{2.5}$ mass. As precursors of sulfate and nitrate, $\mathrm{SO}_{2}$ and $\mathrm{NO}_{\mathrm{x}}$ also showed the highest concentration levels during this episode, which had been stated in Sect. 3.1. This suggested that the pollution during PE1 was dominated by the secondary inorganic aerosol. In addition, we found that during PE3, these species also exhibited a moderate concentration level with an average

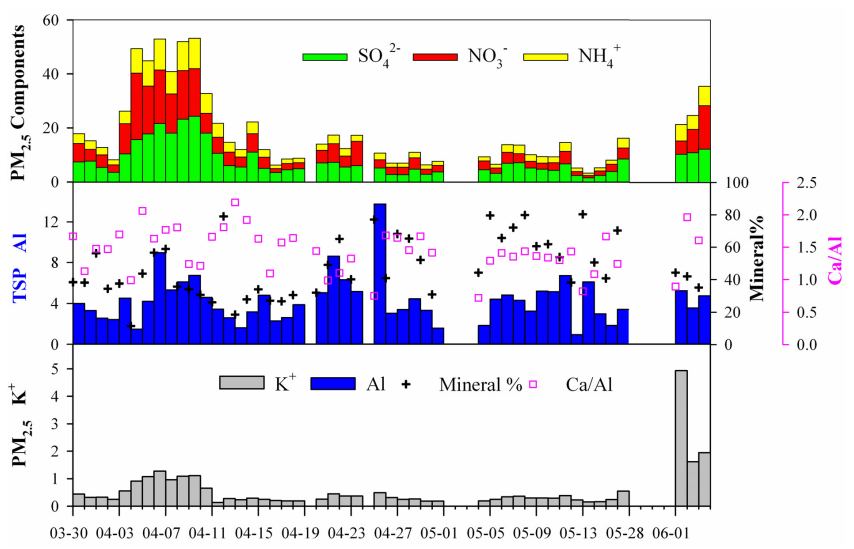

Fig. 6. Time series of (a) $\mathrm{SO}_{4}^{2-}, \mathrm{NO}_{3}^{-}$, and $\mathrm{NH}_{4}^{+}$concentration $\left(\mu \mathrm{g} \mathrm{m}^{-3}\right)$ in $\mathrm{PM}_{2.5}$ (b) $\mathrm{Al}$ concentration $\left(\mu \mathrm{g} \mathrm{m}^{-3}\right)$, the fraction of mineral aerosol, and the elemental ratio of $\mathrm{Ca} / \mathrm{Al}$ in the total suspended particles (TSP) (c) $\mathrm{K}^{+}$in $\mathrm{PM}_{2.5}$, during the whole study period (Missing data were due to rainfall or malfunction of instruments).

value of $27.12 \pm 7.37 \mu \mathrm{g} \mathrm{m}^{-3}$, which probably indicates that biomass burning could also release considerable amounts of inorganic pollutants. For the other periods, the concentration of theses species were much lower with values almost below $20 \mu \mathrm{g} \mathrm{m}^{-3}$. The average sulfate concentration during the whole study period was $8.0 \pm 5.8 \mathrm{\mu g} \mathrm{m}^{-3}$. Compared to previous studies (Fu et al., 2008; Pathak et al., 2009; Wang et al., 2006; Yao et al., 2002; Ye et al., 2003), sulfate concentration was much lower in this study, indicating the effective policy controls on the $\mathrm{SO}_{2}$ emission. However, the average nitrate concentration reached $6.3 \pm 5.7 \mu \mathrm{g} \mathrm{m}^{-3}$, which was comparable or even higher than those previous results. Additionally, the mass ratio of $\mathrm{NO}_{3}^{-} / \mathrm{SO}_{4}^{2-}$ had an increasing trend as compared to the value of $0.75 \pm 0.26$ in this study with 0.64 in 2006 (Wang et al., 2006), and 0.43 during 1999-2000 (Yao et al., 2002; Ye et al., 2003). The ratio of $\mathrm{NO}_{3}^{-} / \mathrm{SO}_{4}^{2-}$ can be used as an indicator of the relative importance of stationary vs. mobile sources (Arimoto et al., 1996). The increasing trend of $\mathrm{NO}_{3}^{-} / \mathrm{SO}_{4}^{2-}$ indicates that the role of mobile emission has become more and more significant due to the rapid expansion of transportation.

Figure $6 \mathrm{~b}$ shows the temporal variations of elemental $\mathrm{Al}$ concentration, the ratio of $\mathrm{Ca} / \mathrm{Al}$, and the estimated mass fraction of mineral aerosol in the total suspended particles (TSP). Al is one of the inert and abundant elements in mineral aerosol and has been used as a good tracer for mineral aerosol in various studies (Huang et al., 2010; Wang et al., 2007; Zhang et al., 2010). As shown in the figure, the highest $\mathrm{Al}$ concentration occurred on April 25, i.e. the second pollution episode (PE2). The daily Al concentration reached a high of $13.7 \mu \mathrm{g} \mathrm{m}^{-3}$, almost 2 to 3 times that of the other periods. To quantify the mass concentration 
of mineral aerosol, it could be estimated by summing the major mineral elements with oxygen for their normal oxides, which was calculated using the formula: [Mineral concentration $]=2.2[\mathrm{Al}]+2.49[\mathrm{Si}]+1.63[\mathrm{Ca}]+2.42[\mathrm{Fe}]$ +1.94 [Ti] (Malm et al., 1994). According to this estimation, the percentage of mineral aerosol in TSP during PE2 was as high as $76.8 \%$. Oppositely, the average concentration of sum of $\mathrm{SO}_{4}^{2-}, \mathrm{NO}_{3}^{-}$, and $\mathrm{NH}_{4}^{+}$in $\mathrm{PM}_{2.5}$ was only $11.23 \pm 5.25 \mathrm{\mu g} \mathrm{m}^{-3}$, which was the lowest during the whole study period. This indicates the dominance of nonanthropogenic sources and the prominent impact of dust entrainment on the local aerosol chemistry. To further characterize the origin of dust, the temporal variation of the elemental $\mathrm{Ca} / \mathrm{Al}$ ratio was investigated, as different dust regions in China are characterized by distinct $\mathrm{Ca}$ content and $\mathrm{Ca} / \mathrm{Al}$ ratios in soils/particles (Zhang et al., 2003, 1996). The $\mathrm{Ca} / \mathrm{Al}$ ratio during $\mathrm{PE} 3$ reached a low value of 0.75 , while in the other period it mainly ranged between 1.0 and 2.0. The relatively high $\mathrm{Ca} / \mathrm{Al}$ ratios during the non-dust periods were attributed to the frequent construction activities in recent years in Shanghai (Wang et al., 2006). The significant drop of $\mathrm{Ca} / \mathrm{Al}$ ratio during PE2 confirmed that the local air quality must have been impacted by outside sources. Elemental ratios of $\mathrm{Ca} / \mathrm{Al}$ of dust aerosol in the three major dust source regions of China, i.e. Gobi Desert, Loess Plateau, and Taklimakan Desert, were $0.52 \pm 0.05,1.09 \pm 0.13$, and $1.56 \pm 0.14$, respectively (Huang et al., 2010). Combined with the backward trajectory analysis in Sect. 3.1, we could confirm that the aerosol chemistry over Shanghai during PE2 was more close to that of the dust aerosol originating from Gobi Desert. During PE1, moderate Al concentrations $\left(5.48 \pm 2.52 \mu \mathrm{g} \mathrm{m}^{-3}\right)$ were observed, indicating the influence from long transported dust aerosol to some extent.

Figure $6 \mathrm{c}$ shows the temporal variation of particulate $\mathrm{K}^{+}$ concentration in $\mathrm{PM}_{2.5}$, which is a good indicator for tracing the biomass burning source (Andreae, 1983). The highest $\mathrm{K}^{+}$concentration was detected just during PE3, with an average concentration of $2.84 \mu \mathrm{g} \mathrm{m}^{-3}$, which was 5 to 10 times higher than the other days. As $\mathrm{K}^{+}$could be also derived from soil and dust, we used the $\mathrm{K} / \mathrm{Fe}$ ratio of 0.56 (Yang et al., 2005b) to exclude the contribution of mineral source. It was calculated that the biomass burning-derived $\mathrm{K}^{+}$could contribute about $80 \%$ of total $\mathrm{K}^{+}$, indicating the significant influence of biomass burning. The total potassium accounted for an average of $3.25 \%$ in $\mathrm{PM}_{2.5}$ during $\mathrm{PE} 3$, which was also higher than that of $1.07 \%$ in the other times and close to that of $3.58 \%$ observed during the Mount Tai Experiment 2006 (MTX2006), which focused on biomass burning in Eastern China (Deng et al., 2010). $\mathrm{Cl}^{-}$and $\mathrm{K}^{+}$are both important ions in particles from open burning of agricultural wastes ( $\mathrm{Li}$ et al., 2007a). Individual particle analysis has found that large irregular shaped $\mathrm{KCl}$ particles existed in young smoke (Chakrabarty et al., 2006; Li et al., 2003). During PE3, a very significant correlation between $\mathrm{Cl}^{-}$and $\mathrm{K}^{+}$ was observed with the correlation coefficient of 0.96 . The $\mathrm{K}^{+} / \mathrm{Cl}^{-}$ratio of 2.09 during PE3 was much higher than its background ratio of 0.10 to 0.46 (Wang et al., 2006), indicating the dominance of biomass burning source. However, $\mathrm{Cl}^{-}$ could be also derived from coal burning as coal had always contributed to the biggest share of the energy structure in Shanghai. Another significantly enhanced group of aerosol was the organic aerosol, including organic carbon (OC) and element carbon (EC). $\mathrm{OC}$ and $\mathrm{EC}$ in $\mathrm{PM}_{10}$ averaged 35.8 \pm 8.1 and $5.7 \pm 1.3 \mu \mathrm{g} \mathrm{m}^{-3}$ during PE3, and they were enhanced $30-100 \%$ compared to the other days. The concentration of organic aerosol was comparable to the extensive burning biomass period during MTX2006 (EC: $7 \mu \mathrm{g} \mathrm{m}^{-3}$, OC: $24 \mu \mathrm{g} \mathrm{m}^{-3}$ ) (Yamaji et al., 2010). If an OM/OC ratio of 1.8 was applied to estimate the mass of organic matter (OM) (Turpin and Lim, 2001), the average mass contribution of $\mathrm{OM}$ to $\mathrm{PM}_{10}$ would be as high as $50 \%$. Furthermore, a higher factor (2.2-2.6) for aerosol heavily impacted by smoke was recommended (Turpin and Lim, 2001), thus it may result in an underestimated value for the faction of OM in this work. Compared to previous results of the mass percentage of organic aerosol of $\sim 30 \%$ over YRD in the non-biomass-burning times (Feng et al., 2009; Yang et al., 2005a), biomass burning evidently emitted much more hydrocarbons. The OC/EC ratio is commonly on the order of 3 in most urban cities of China (Zhang et al., 2008), where the major sources of OC and EC are dominated by fossil fuel combustions. High ratio of OC/EC (6.4) was observed during PE3, which indicated that biomass burning contributed far more organic carbon than fossil fuel combustion did (Yan et al., 2006). Field measurements have also observed a high ratio of OC/EC (about 5) for the burning of wheat straw and an even higher ratio for maize stover (Li et al., 2007).

Figure 7 shows the enrichment factors (EF) of major elements in $\mathrm{PM}_{2.5}$ during three episodes, respectively, which aims to evaluate the enrichment extents of various elements in aerosol. Usually, $\mathrm{Al}$ is used as the reference element as it is a relatively chemical inert element with almost no anthropogenic sources. The calculation formula was $\mathrm{EF}_{\mathrm{x}}=(X / \mathrm{Al})_{\text {aerosol }} /(X / \mathrm{Al})_{\text {crust }}$, of which $X$ was the element of interest. Species with EFs less than 10 were usually considered to have a major natural source, which included Sc, $\mathrm{Na}, \mathrm{Ca}, \mathrm{Co}, \mathrm{Fe}, \mathrm{Mn}, \mathrm{Sr}, \mathrm{Ba}, \mathrm{P}, \mathrm{K}, \mathrm{Ni}, \mathrm{Mn}, \mathrm{Ti}$, and V. The $\mathrm{EF}$ of $\mathrm{V}$ was a little higher during PE1, which could be from the re-suspension of local soils and road pavement erosion (Amato et al., 2009). Species with higher EFs were contaminated by anthropogenic sources, which included $\mathrm{Cu}, \mathrm{Mo}$, $\mathrm{As}, \mathrm{Sb}, \mathrm{Ge}, \mathrm{Pb}, \mathrm{Zn}, \mathrm{Cd}, \mathrm{S}$, and $\mathrm{Se}$. As shown in the figure, the enrichment degrees of almost all the elements were the lowest during PE2. The dust aerosol originating from the Gobi Desert was relatively clean (Huang et al., 2010), and its entrainment had a cleanup and dilution effect on the local pollution, which lowered the enrichment degrees of most pollution elements. Elements during PE1 were mostly enriched, especially for those elements, i.e. $\mathrm{Pb}, \mathrm{Zn}, \mathrm{Cd}, \mathrm{S}$, and 


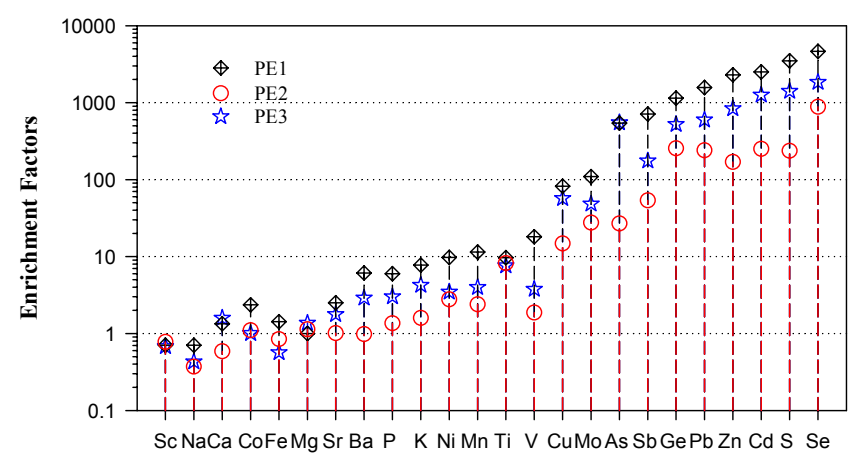

Fig. 7. The average enrichment factors $(\mathrm{EF})$ of various elements during PE1, PE2, and PE3, respectively.

$\mathrm{Se}$, with EF values larger than $1000 . \mathrm{Pb}$ had its major source from traffic emission in early years, while coal combustion has dominated as the lead pollution source since the phasing out of leaded gasoline in 1997 in Shanghai (Chen et al., 2005; Tan et al., 2006; Zhang et al., 2009). Zn and Cd are mainly derived from local industrial and traffic emission (Cao et al., 2008; Shi et al., 2008). As indicators for coal combustion (Nriagu, 1989), S and Se had the highest EFs among all the elements, indicating coal combustion is one of the major sources of air pollution in Shanghai. Most of the EFs of pollution elements during the biomass burning period, i.e. PE3, were higher than PE2 and lower than PE1. The only exception was arsenic (As), whose EF was comparable to that during PE1. The average As concentration during PE3 was $7.53 \mathrm{ng} \mathrm{m}^{-3}$, higher than that of $4.46 \mathrm{ng} \mathrm{m}^{-3}$ during PE1 and much higher than $2.02 \mathrm{ng} \mathrm{m}^{-3}$ in the normal periods. The high concentration and great enrichment of As was probably not derived from its usual source such as coal burning, as no corresponding enrichment of the other pollution elements were found as in the PE1 case. High arsenic levels in groundwater in many areas over mainland China have been observed (Mandal and Suzuki, 2002) and crops are most susceptible to As toxicity, which is sourced from the As-contaminated groundwater used for irrigation (Brammer and Ravenscroft, 2009). Thereby, the burning of agricultural residues would probably release considerable amounts of As, resulting in the enrichment of As in particles.

\subsection{Aerosol vertical profile}

Figure 8 shows the time-height cross-section of the lidar measured aerosol properties at the wavelength of $532 \mathrm{~nm}$ during the three pollution periods, respectively. In this study, the total aerosol extinction coefficient was split to non-dust (spherical aerosols such as air pollution) and dust (nonspherical aerosol) fractions based on the aerosol depolarization ratio. Sugimoto et al. (2002) and Shimizu et al. (2004) described details of lidar observation and splitting method. Figure 8a presents the time-height cross-section of spheric aerosol extinction coefficient during PE1. Lidar observation successfully captured several high extinction peaks, which was consistent with the ground monitoring (Fig. 1b). Vertical distribution of aerosol extinction coefficient exhibited strong variations and showed obvious decreasing gradients from the ground to upper layers, which reflected that pollutants were mainly constrained near the surface ground. The height of the boundary layer could be visually assumed from the vertical profile of aerosol optical properties. The profile, where the extinction coefficient sharply decreased, could be determined as the top of planetary boundary layer (PBL) (Noh et al., 2007). During the daytime, the PBL height was relatively high, and sometimes it could reach up to $2 \mathrm{~km}$, which was due to the higher temperature and stronger air convection. While during nighttime, it dropped to less than $0.5 \mathrm{~km}$ due to the temperature inversion. We selected one typical day (11:30-15:00 LST, 6 April) during PE1 to discuss its vertical profile (Fig. 9a). The depolarization ratio at the wavelength of $532 \mathrm{~nm}\left(\delta_{532}\right)$ from the ground to the upper layer $(\sim 1.5 \mathrm{~km})$ was less than $5 \%$, indicating the aerosol was mainly composed of spheric particles. While at higher altitudes, the depolarization ratio increased slightly, which may due to the absence of spheric aerosol or the possible contamination of water clouds and ice clouds. The averaged profile of attenuated aerosol backscattering coefficient showed a steep decreased gradient from $0.037 \mathrm{~km}^{-1} \mathrm{sr}^{-1}$ near the ground to $0.0018-0.0030 \mathrm{~km}^{-1} \mathrm{sr}^{-1}$ around $1-1.5 \mathrm{~km}$.

As for PE2, we present the time-height cross-section of spheric aerosol extinction coefficient and depolarization ratio measured during 22-28 April (Fig. 8b). The depolarization ratio showed high values on 25 April. The high depolarization ratio of aerosol was due to the nonsphericity (irregular shapes) and relatively large size of particles (Mcneil and Carswell, 1975), we regarded this type of aerosol as mineral aerosol/dust aerosol since dust was the most important component of nonspheric aerosols in East Asia. On 25 April, two consecutive dust plumes were observed, which was consistent with the ground measurement. Before the dust event, the air quality was relatively good. The high extinction coefficients and low mixing layers (400-600 m) of the whole day on 24 April were caused by the recorded rainfall. It should be emphasized that on the advent of the first dust plume (01:30-08:00 LST), the extinction coefficients of spheric aerosol were still high, indicating the strong mixing of dust and pollutant aerosol. After the pass of dust, the values decreased, indicating the clear-out of pollutants. The pollutants concentration increased again after the advent of the second dust plume (13:00-21:45 LST). One dust plume (01:3008:00 LST, 25 April) was selected to portray its vertical profile (Fig. 9b). In addition to the profile of aerosol backscattering coefficient and total depolarization ratio, the fraction of dust aerosol extinction to the total aerosol extinction $\left(f_{\mathrm{d}}\right)$ was also calculated based on the splitting method described by (Shimizu et al., 2004; Sugimoto et al., 2002). Compared to PE1, and PE3 that will be discussed below, PE2 showed 

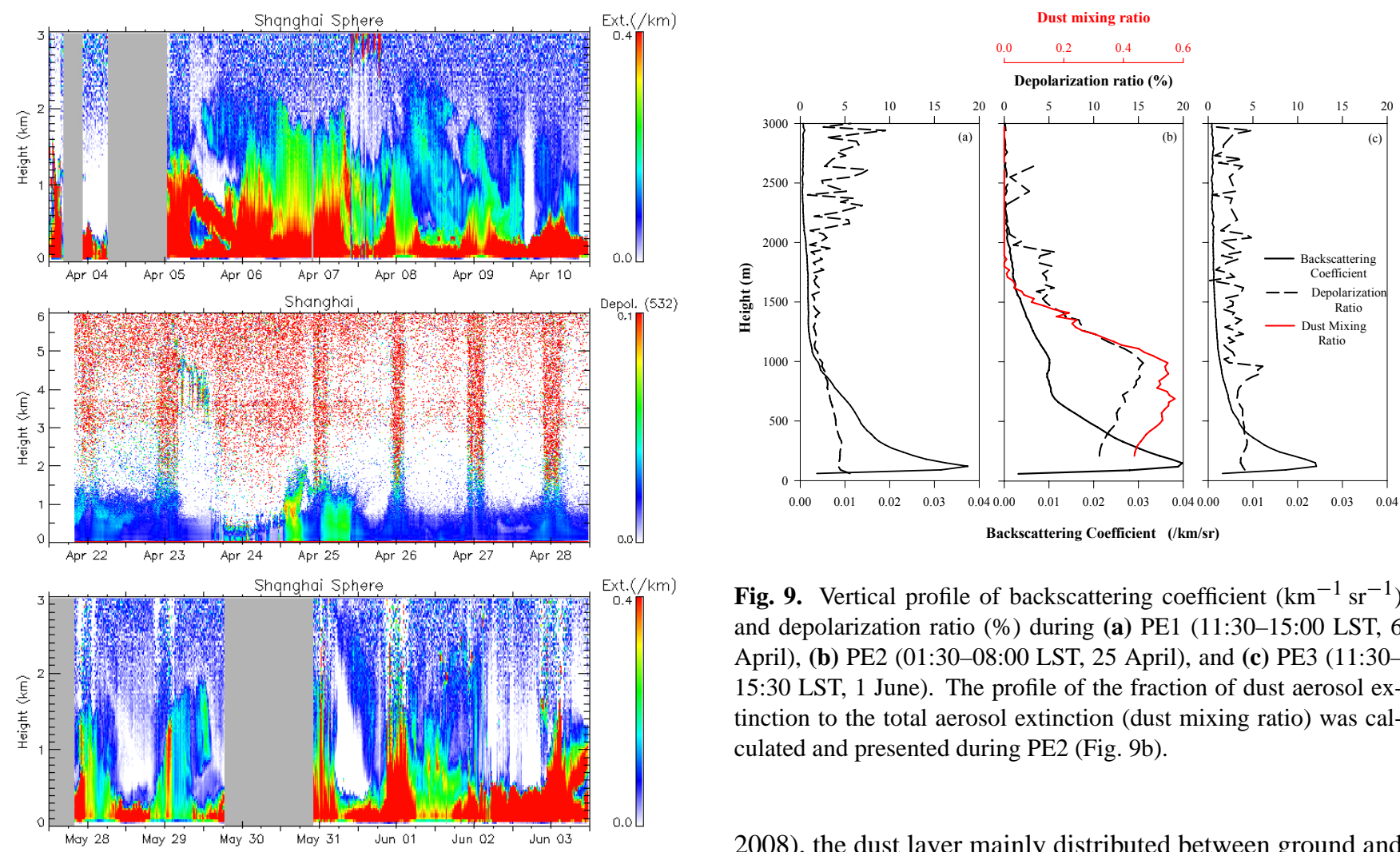

Fig. 9. Vertical profile of backscattering coefficient $\left(\mathrm{km}^{-1} \mathrm{sr}^{-1}\right)$ and depolarization ratio (\%) during (a) PE1 (11:30-15:00 LST, 6 April), (b) PE2 (01:30-08:00 LST, 25 April), and (c) PE3 (11:3015:30 LST, 1 June). The profile of the fraction of dust aerosol extinction to the total aerosol extinction (dust mixing ratio) was calculated and presented during PE2 (Fig. 9b).

Fig. 8. Top panel: The time-height cross section of spheric aerosol extinction coefficient $\left(\mathrm{km}^{-1}\right)$ during PE1. Middle panel: the timeheight cross section of depolarization ratio from 22-28 April, including PE2 (25 April). Bottom panel: the time-height cross section of spheric aerosol extinction coefficient $\left(\mathrm{km}^{-1}\right)$ during PE3. The gray columns represented the missing data which were due to the malfunction of the lidar instrument.

an evidently different profile. The backscattering coefficient sharply decreased from $0.04 \mathrm{~km}^{-1} \mathrm{sr}^{-1}$ at near surface to $0.01 \mathrm{~km}^{-1} \mathrm{sr}^{-1}$ at around $0.7 \mathrm{~km}$. And then the coefficient almost stayed constant value of about $0.01 \mathrm{~km}^{-1} \mathrm{sr}^{-1}$ between 0.7 and $1.0 \mathrm{~km}$, which indicated the transport of outside aerosol, a phenomenon not observed in the other two episodes. Upwards, the backscattering coefficient started to sharply decrease again to low values. The vertical distribution of backscattering coefficient was closely related to the profile of depolarization ratio. As shown in Fig. 9b, there was an increase of $\delta_{532}$ from ground and peaked at around $1.0 \mathrm{~km}$ with a value of 0.155 . Correspondingly, the contribution of dust aerosol extinction to the total aerosol extinction peaked between 0.7 and $1.0 \mathrm{~km}$ with the values ranging from $51 \%$ to $57 \%$. Thus, the relatively constant backscattering coefficient between altitudes of 0.7 and $1.0 \mathrm{~km}$ should be due to the increase of dust aerosol. Above this layer, $f_{\mathrm{d}}$ was less than $10 \%$, indicating the negligible existence of nonspheric aerosol in the upper layers. Using a threshold of $\delta_{532}=0.06$ to distinguish dust from other types of aerosol (Liu et al.,

2008), the dust layer mainly distributed between ground and up to an altitude of around $1.4 \mathrm{~km}$. The average $\delta_{532}$ of this layer was $0.122 \pm 0.023$, which was close to the dust observed in Korea that originated from the same dust region (Kim et al., 2010). $\delta_{532}$ decreased above this layer, indicating that dust was transported at relatively low altitudes. Actually, most of the dust plumes (approximately $70 \%$ ) were observed near the ground (Kim et al., 2010). The contribution of dust aerosol extinction to the total aerosol extinction exhibited high values and relatively small vertical variations from the near surface to the upper layer of around $1 \mathrm{~km}$, ranging from $44 \%$ to $55 \%$. If we applied the dust and soluble aerosol extinction efficiency $\left(\sigma_{\mathrm{ep}}\right)$ of about 0.5 and $3 \mathrm{~m}^{2} \mathrm{~g}^{-1}$, respectively (Lee et al., 2009), it could be estimated that the mass concentration of dust aerosol was almost 4 to 7 times that of spheric aerosol by using the formula, $\sigma_{\mathrm{ep}}=\beta_{\mathrm{ext}} / M$, of which $\beta_{\text {ext }}$ and $M$ represented the extinction coefficient and mass concentration of dust/spheric aerosol. This was consistent with our ground measurement that dust aerosol contributed $76.8 \%$ to the total aerosol mass as discussed in Sect. 3.3.

Figure $8 \mathrm{c}$ shows the time-height cross-section of spheric aerosol extinction coefficient during PE3. The high aerosol extinction coefficients and strong temporal variations during PE3 were similar to PE1; however, the PBL height was even lower. Figure 9c shows the vertical profile of backscattering coefficient and depolarization ratio on 1 June (11:30-15:30 LST). The depolarization ratio fluctuated within 0.05 in the whole layer, indicating the dominance of spheric particles. The backscattering coefficient was about $0.024 \mathrm{~km}^{-1} \mathrm{sr}^{-1}$ near the surface, much lower 


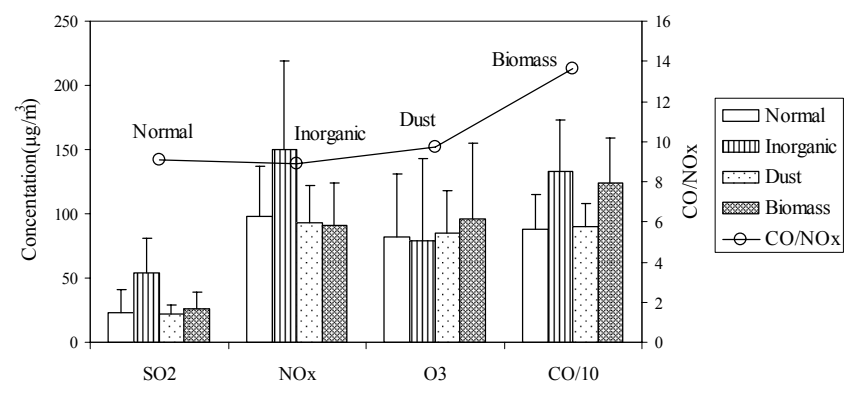

Fig. 10. The average concentrations of $\mathrm{SO}_{2}, \mathrm{NO}_{\mathrm{x}}, \mathrm{O}_{3}$ and $\mathrm{CO}$ during the normal period, PE1 (inogranic), PE2 (dust), and PE3 (biomass), respectively. The concentrations of $\mathrm{CO}$ were divided by 10 for scale visualization, and the ratios of $\mathrm{CO} / \mathrm{NO}_{\mathrm{x}}$ were also calculated and shown in the figure. Error bars represented one standard deviation of the gaseous concentrations during different periods.

than PE1 and PE2, whereas the fine aerosol concentration during PE3 was the highest. The non-linearity between fine PM concentrations and optical properties should be due to the different chemical compositions among different periods. Organic aerosol dominated during biomass burning episode, while sulfate ammonium, nitrate ammonium dominated during the secondary inorganic pollution episode. The mass scattering efficiency $\left(\mathrm{m}^{2} \mathrm{~g}^{-1}\right)$ of organics was about a factor of 2 to 3 lower than that of sulfate (Hasan and Dzubay, 1983; Ouimette and Flagan, 1982); thus, this discrepancy resulted in the non-linearity between PM concentrations and optical properties.

\subsection{Trace gases}

Figure 10 compares the concentrations of trace gases among three pollution episodes and the normal period. The normal period was defined as the remaining days excluding the three pollution episodes. $\mathrm{O}_{3}$ during $\mathrm{PE} 1$ was the lowest with average concentration of $79 \pm 63 \mu \mathrm{g} \mathrm{m}^{-3}$, and $\mathrm{O}_{3}$ and $\mathrm{NO}_{\mathrm{x}}$ were strongly anti-correlated, which was due to the titration effect of nitrogen oxides as the Yangtze River Delta was under a strong VOC-limited regime (Geng et al., 2009). $\mathrm{O}_{3}$ was highest during PE3 with an average concentration of $96 \pm 63 \mu \mathrm{g} \mathrm{m}^{-3}$, which could be caused by both the relatively high emission of hydrocarbons from biomass burning and the relatively weak titration effect of $\mathrm{NO}_{\mathrm{x}}$. During PE1, the average concentrations of $\mathrm{SO}_{2}, \mathrm{NO}_{\mathrm{x}}$ and $\mathrm{CO}$ reached 54, 150 , and $1334 \mu \mathrm{g} \mathrm{m}^{-3}$, respectively. Compared to the heaviest pollution recorded at Shanghai on 19 January in 2007 , when the daily concentration of $\mathrm{SO}_{2}$ and $\mathrm{NO}_{2}$ reached 194 and $123 \mathrm{~g} \mathrm{~m} \mathrm{~m}^{-3}$, respectively (Fu et al., 2008), the concentration of $\mathrm{SO}_{2}$ in this study was obviously lower, which could be due to the energy policies in China that mitigated $\mathrm{SO}_{2}$ emission, including desulfurization of coal-fired power plant plumes, decommissioning of coal-fired boilers in manufacturing facilities and small power plants, conversion of do- mestic coal use to cleaner fuels, etc. (Fang et al., 2009). The emission of $\mathrm{SO}_{2}$ remained almost constant from 1996-2005 (Chan and Yao, 2008) and recent studies show that $\mathrm{SO}_{2}$ emissions started decreasing in China after 2006 (Li et al., 2010; Lu et al., 2010). Nitrogen oxides would be the major pollutant to be concerned about for the present and future. The average concentration of $\mathrm{NO}_{2}$ and $\mathrm{NO}_{\mathrm{x}}$ during $\mathrm{PE} 1$ reached high levels of 109 and $150 \mathrm{\mu g} \mathrm{m}^{-3}$, respectively. Even during the normal period, their average concentration was 60 and $99 \mu \mathrm{g} \mathrm{m}^{-3}$, respectively, contrasting to 3-40 ppbv $\mathrm{NO}_{\mathrm{x}}$ ( 1 ppbv $\mathrm{NO}_{\mathrm{x}}$ equaled to about $1.9 \mu \mathrm{g} \mathrm{m}^{-3}$ ) in 2007 (Geng et al., 2009) and 5-35 $\mu \mathrm{g} \mathrm{m}^{-3} \mathrm{NO}_{\mathrm{x}}$ in 1999 (Wang et al., 2003). Satellite observation and model simulation both detected and predicted a strong increase of $\mathrm{NO}_{2}$ in Eastern China, especially after 2000 (He et al., 2007), and Shanghai had a significantly linear increase of $\mathrm{NO}_{2}$ column concentrations with about $20 \%$ per year during the period of 1996-2005 (van der A et al., 2006), which was the rapidest among all the megacities in China (Zhang et al., 2007). Therefore, the relatively high concentration of particulate nitrate and increasing ratio of $\mathrm{NO}_{3}^{-} / \mathrm{SO}_{4}^{2-}$ stated in Sect. 3.3 could be well explained. Correspondingly, the effect of enormous vehicle emissions have also been reflected in the carbon monoxide level. A significant correlation between $\mathrm{CO}$ and $\mathrm{NO}_{\mathrm{x}}$ during PE1 was observed with the correlation coefficient of 0.86 , indicating their common sources. Average concentration of $\mathrm{CO}$ during PE1 reached $1334 \pm 884 \mu_{g^{-3}}{ }^{-3}$, greatly enhanced as compared to the normal period of $884 \pm 267 \mu \mathrm{g} \mathrm{m}^{-3}, 500-$ $900 \mu \mathrm{g} \mathrm{m}^{-3}$ in 1999 (Wang et al., 2003) and $654 \mathrm{ppbv}$ ( $1 \mathrm{ppbv}$ $\mathrm{CO}$ equaled to about $1.2 \mu \mathrm{g} \mathrm{m}^{-3}$ ) in 2005 (Zhou et al., 2009). Due to increases of vehicle population and mileages in China, the emissions of $\mathrm{NO}_{\mathrm{x}}$ and $\mathrm{CO}$ apportioned to vehicular emission inventory have increased at an annual rate of $15 \%$ and $14 \%$ from 1980 to 2005, respectively. Especially, the Yangtze River Delta, which covered only $2.2 \%$ of the total territory of China, generated about $19 \%$ of total vehicular pollutants in 2005 (Cai and Xie, 2007).

During the biomass burning period, the concentrations of $\mathrm{SO}_{2}$ and $\mathrm{NO}_{\mathrm{x}}$ were much lower than during PE1 and close to the normal period. However, $\mathrm{CO}$ was considerably enhanced with an average concentration of $1241 \pm 352 \mu \mathrm{g} \mathrm{m}^{-3}$, which was close to PE1 and much higher than the other periods. This was because biomass burning can release large amounts of $\mathrm{CO}$ while contributing little to the $\mathrm{SO}_{2}$ and $\mathrm{NO}_{\mathrm{x}}$ emission. Laboratory and filed measurements of several types of crops in Eastern China showed that the emission factor of $\mathrm{SO}_{2}\left(0.44-0.85 \mathrm{~g} \mathrm{~kg}^{-1}\right)$ and $\mathrm{NO}_{\mathrm{x}}\left(1.12-4.3 \mathrm{~g} \mathrm{~kg}^{-1}\right)$ was far less than that of $\mathrm{CO}\left(53-141.2 \mathrm{~g} \mathrm{~kg}^{-1}\right)$ and $\mathrm{CO}_{2}(791.3-$ $1557.9 \mathrm{~g} \mathrm{~kg}^{-1}$ ) (Andreae and Merlet, 2001; Li et al., 2007a; Zhang et al., 2008), indicating $\mathrm{SO}_{2}$ and $\mathrm{NO}_{\mathrm{x}}$ were not the major gaseous pollutants emitted from biomass burning in this region. Figure 11 further compares the diurnal variations of $\mathrm{CO}$ and $\mathrm{NO}_{\mathrm{x}}$ between PE3 and the normal period, respectively. It was found that there was almost no difference between the two periods for diurnal variation of $\mathrm{NO}_{\mathrm{x}}$, while 
great distinction existed for CO. During the normal period, usually two peaks would be observed: the morning (06:0009:00 LST) and evening (17:00-20:00 LST) rush hours due to enhanced vehicular emission in big cities (Andreae et al., 2008; Tie et al., 2009). While during the biomass burning period, CO peaks evidently shifted to random times at around 08:00-10:00 and 14:00-16:00 LST, which may reflect the emission characteristics of local burning activities and transporting time from outside burning areas. The diurnal variation in this study was more or less similar to the profile based on fire observations from satellite over 15 tropical and subtropical regions (Giglio, 2007). Another distinct difference between the two periods was that the hourly $\mathrm{CO}$ concentrations during PE3 were all higher than the normal period, while there was negligible difference for $\mathrm{NO}_{\mathrm{x}}$, precluding the possible enhancement of vehicle emission that can cause an increase of $\mathrm{CO}$. The results above suggested that the $\mathrm{CO} / \mathrm{NO}_{\mathrm{x}}$ ratio might serve to distinguish biomass burning from the other emission sources. Figure 10 presents the calculated average $\mathrm{CO} / \mathrm{NO}_{\mathrm{x}}$ ratios during four periods.

The ratio of NP, PE1, and PE2 were very close, which ranged from 9 to 10; while it was much higher during PE3 with average value of 14 . During the non-biomass-burning period, $\mathrm{CO}$ and $\mathrm{NO}_{\mathrm{x}}$ mainly derived from stationary (industry) and mobile (transportation) sources. No matter what type of dominated pollution, i.e. secondary inorganic aerosol, dust aerosol, or the normal period, the emission factors of fossil fuels would not change much, thus the emission amounts of specific pollutants should almost be proportional regardless of the total emissions. That explains why we found that the $\mathrm{CO} / \mathrm{NO}_{\mathrm{x}}$ ratio did not vary much among NP, PE1, and PE2. As viewed from the emission inventory, it was calculated that the $\mathrm{CO} / \mathrm{NO}_{\mathrm{x}}$ ratio of the INTEX-B non-biomass-burning inventory (i.e. sum of transportation, industry, domestic, large and small power plants emission inventory) (Zhang et al., 2009) was 7.4 for the grid cell of YRD, very close to the measurement results of this study. However, the $\mathrm{CO} / \mathrm{NO}_{\mathrm{x}}$ ratio of the biomass emission inventory was much higher than 24 . By using a simple mixing model, in which the $\mathrm{CO} / \mathrm{NO}_{\mathrm{x}}$ ratio in non-biomass-burning and in biomass burning period was assumed to be 7.4 and 24 , respectively, we could roughly estimate that biomass burning accounted for a significant contribution of about $40 \%$ to the total CO emission in this study.

\subsection{Formation mechanisms of different types of haze}

Correlation analysis was able to shed some light on the mechanisms of haze formation under different conditions. Figure 12 demonstrates the linear relationship between gaseous pollutants $\left(\mathrm{SO}_{2}, \mathrm{NO}_{\mathrm{x}}\right.$ and $\left.\mathrm{CO}\right)$ and particulate matters $\left(\mathrm{PM}_{2.5}\right)$. During PE1, significant correlations were observed among all the three gaseous species and $\mathrm{PM}_{2.5}$ with correlation coefficients $(R)$ larger than 0.70 (Fig. 12a-c). As precursors of sulfate and nitrate, the good correlations between $\mathrm{SO}_{2} / \mathrm{NO}_{\mathrm{x}}$ and $\mathrm{PM}_{2.5}$ were predictable, which corroborated

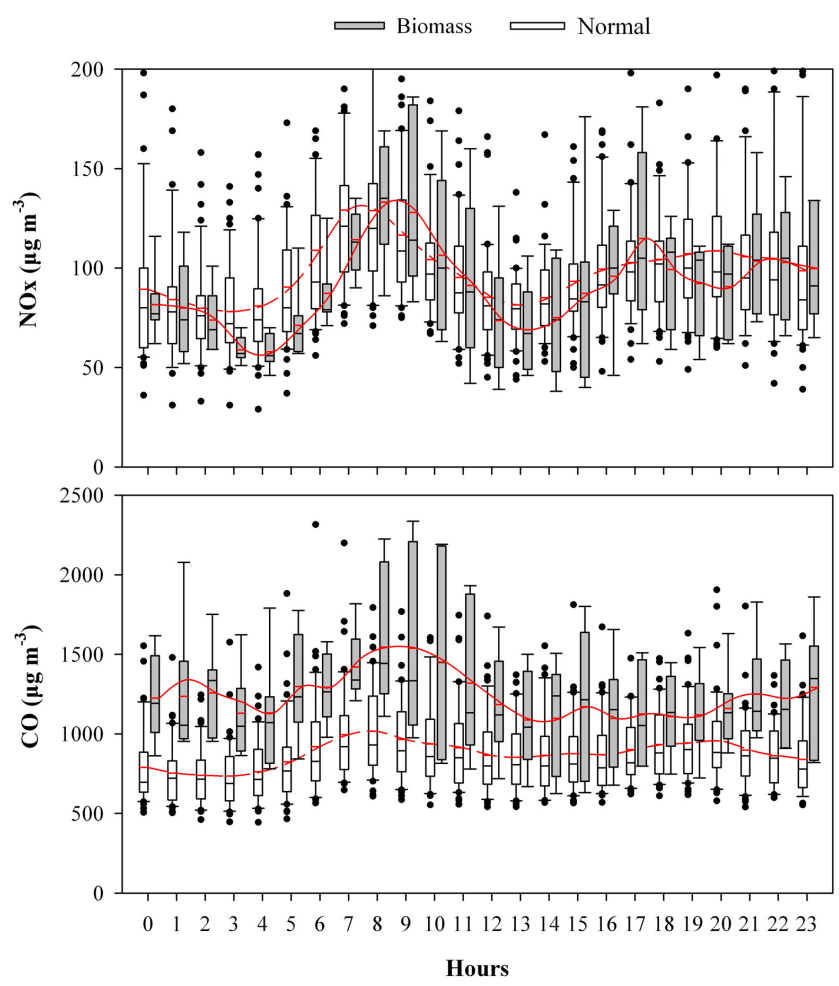

Fig. 11. The diurnal variation of $\mathrm{CO}$ and $\mathrm{NO}_{\mathrm{x}}$ concentrations $\left(\mu \mathrm{g} \mathrm{m}^{-3}\right.$ ) during the biomass burning period (gray box) and normal period (white box), respectively. Diurnal mean values are connected by the red spline curves; bottom and top of the boxes represent the 25 and $75 \%$ limits, respectively; and bottom and top short lines represent the minimum and maxium values, respectively. Black dots represent the outliers.

the results that sulfate and nitrate dominated the aerosol composition during PE1. Although CO could not act as precursor of secondary aerosol, we still found its good correlation with $\mathrm{PM}_{2.5}(R=0.71)$. That is because $\mathrm{CO}$ was highly correlated with $\mathrm{NO}_{\mathrm{x}}$ as stated above, which indirectly linked itself to $\mathrm{PM}_{2.5}$. During PE2, there was only weak correlation between pollutant gases and aerosol (not shown in the figure), as the aerosol during this period was dominated by the minerals. Figure 12d-f shows the different correlation pattern for PE3 compared to PE1. As indicated by the correlation coefficients, $\mathrm{NO}_{\mathrm{x}}$ had weak correlation with $\mathrm{PM}_{2.5}(R=0.41)$ and $\mathrm{SO}_{2}$ even had no correlation with $\mathrm{PM}_{2.5}(R=0.11)$, suggesting secondary inorganic aerosol contributed little to aerosol formation. The significant correlation was only found between $\mathrm{CO}$ and $\mathrm{PM}_{2.5}$ with high correlation coefficient of 0.80 . Anyway, this correlation was different from PE1 and did not mean vehicle or industry emission played a significant role in the aerosol formation as $\mathrm{NO}_{\mathrm{x}}$ was weakly correlated with $\mathrm{PM}_{2.5}$. In Sects. 3.3 and 3.5, we had demonstrated that organic aerosol accounted for a major fraction of particle mass, accompanied with high concentration of $\mathrm{CO}$ derived 

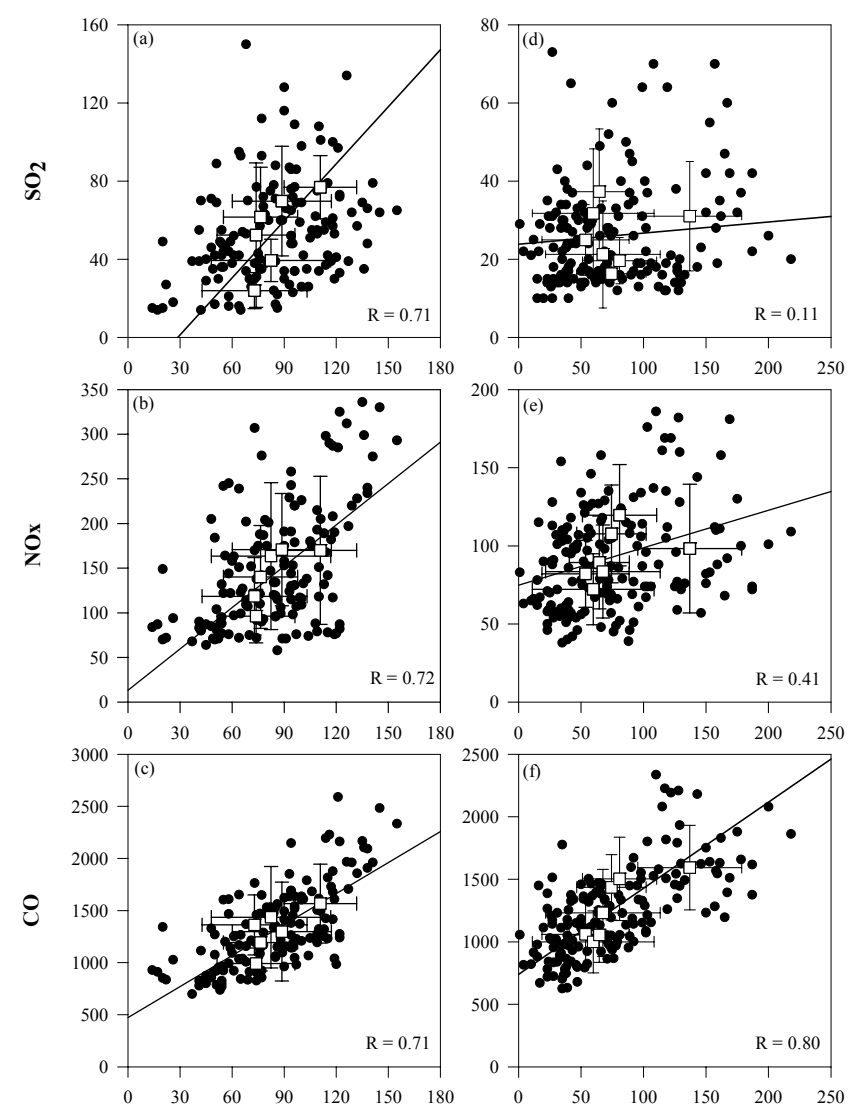

$\mathbf{P M}_{2.5}$

Fig. 12. The linear correlation between gaseous pollutants $\left(\mathrm{SO}_{2}\right.$, $\mathrm{NO}_{\mathrm{x}}$ and $\mathrm{CO}$ ) and $\mathrm{PM}_{2.5}$, with correlation coefficients $(R)$ shown in the figure. Figure $(\mathbf{a}-\mathbf{c})$ denote PE1 and $(\mathbf{d}-\mathbf{f})$ denote PE3. The black dots denote the hourly data and the square symbols denote the daily average data, all units are in $\mu \mathrm{g} \mathrm{m}^{-3}$.

from biomass burning. Correlation between $\mathrm{CO}$ columns and AOD from many varied forest fire episodes overall the different time periods were found (Paton-Walsh et al., 2004). Sun et al. (2009) had observed that CO highly correlated with OA (organic aerosol) $(R: 0.7-0.9)$ in several OA dominated events by using an Aerodyne High Resolution Timeof-Flight Aerosol Mass Spectrometer (HR-ToF-AMS). Although there were no OC data of high time resolution available due to restrictions of instruments in this study, the exclusive correlation between $\mathrm{CO}$ and $\mathrm{PM}_{2.5}$ during the biomass burning events mirrored the dominance of organic aerosol in the particle formation. $\mathrm{CO}$ could be regarded as the proxy of organic aerosol when biomass burning dominated. As visualized in Fig. 12c-f, it was found that the $\mathrm{CO} / \mathrm{PM}_{2.5}$ slope was higher in PE1 than in PE3. The CO level was similar between PE1 and PE3 as shown in Fig. 10. Thus, the lower $\mathrm{CO} / \mathrm{PM}_{2.5}$ slope in PE3 was due to higher $\mathrm{PM}_{2.5}$ concentrations as discussed in Sect. 3.1. This probably meant that biomass burning could produce higher aerosol mass than the industrial/traffic emission as most of the biomass burning events were incomplete combustion, which could not effectively oxidize the hydrocarbon to $\mathrm{CO}_{2}$ or $\mathrm{CO}$.

\section{Conclusions}

An intensive aerosol and trace gases campaign was carried out over the Yangtze River Delta region in Eastern China from April to June, 2009. Three pollution episodes were identified based on the atmospheric visibility, aerosol mass concentrations in different sizes, mass fraction of fine particles, and modeled air trajectories. Distinct characteristics were observed among the three pollution episodes by using a synergy of ground-based measurement, satellite and lidar observation. Three typical types of air pollution causing the haze weather in Eastern China were identified, i.e. secondary inorganic pollution, dust invasion and biomass burning.

1. During the secondary inorganic pollution episode, high AOD (>1.2) and relatively high Angstrom exponent (0.8-1.2) over the Eastern China region was detected by MODIS. The major components of $\mathrm{PM}_{2.5}$ were sulfate, nitrate and ammonium. The sum of these three species reached $48.86 \pm 5.01 \mu \mathrm{g} \mathrm{m}^{-3}$ and accounted for a dominant mass fraction of $77 \%$ in $\mathrm{PM}_{2.5}$. High concentrations of $\mathrm{SO}_{2}, \mathrm{NO}_{\mathrm{x}}$ and $\mathrm{CO}$ and good correlations among these trace gases and $\mathrm{PM}_{2.5}$ indicated that anthropogenic sources (coal burning, vehicle emission, etc.) were the major causes.

2. During the dust pollution episode, high AOD $(>1.2)$ and low Angstrom exponent (0.5-0.6) were observed in Northern and Eastern China, indicating the existence of considerable coarse particles. Mineral aerosol accounted for $76.8 \%$ of the total suspended particles (TSP) and the $\mathrm{Ca} / \mathrm{Al}$ elemental ratio dropped to a relatively low value of 0.75 , which indicated its dust source region in Gobi Desert.

3. The biomass burning pollution episode was characterized of high column concentrations of $\mathrm{CO}, \mathrm{HCHO}$ and AOD, which were observed over the regions with dense fire spots. Particulate components such as $\mathrm{K}^{+}, \mathrm{OC}$ and EC were greatly enhanced as well as the ratio of OC/EC. The organic aerosol was estimated to account for over $50 \%$ to $\mathrm{PM}_{10}$. The significant correlation between $\mathrm{CO}$ and $\mathrm{PM}_{2.5}$, in addition to the weak correlations between $\mathrm{SO}_{2}, \mathrm{NO}_{\mathrm{x}}$ and $\mathrm{PM}_{2.5}$, corroborated that organic aerosol was the major species during biomass burning.

4. The enrichment factor analysis demonstrated that most elements were the least enriched during dust pollution, while the most enriched during the secondary inorganic pollution. One exception is arsenic (As), of which the concentration and enrichment degree were highest during the biomass burning period. We speculated that the 
biomass burning emission could be a more significant source of As other than its usual source of coal burning. This finding highlights the potential threat of arsenic polluted water and soil to the contamination of crops in East Asia.

5. Lidar measurement revealed that aerosol were mainly composed of spheric particles (deplorization ratio $\delta_{532}<5 \%$ ) during the secondary inorganic pollution and biomass burning episodes, while the average $\delta_{532}$ value of the boundary layer was $0.122 \pm 0.023$ during the dust episode, indicating existence of considerable coarse particles. The profile of backscattering coefficient had a sharp decrease with altitudes in the secondary inorganic and biomass pollution episodes. During the dust episode, the dust layer contributed about $51-57 \%$ to the total aerosol extinction at the altitude of $0.7-1.0 \mathrm{~km}$, which compensated the decrease of spheric aerosol extinction and resulted in a different profile from the other two episodes.

\section{Appendix A}

In order to compare with the recorded visibility data, we calculated the near-surface extinction coefficient caused by aerosol $\left(\sigma_{\mathrm{ep}}\right)$ by averaging the lidar measured aerosol extinction coefficient from the ground to an altitude of $300 \mathrm{~m}$. Absorption of visible light by gases was considered to be essentially due to $\mathrm{NO}_{2}$ and the absorption coefficient $\left(\sigma_{\mathrm{ag}}\right)$ could be estimated using the formula $\sigma_{\mathrm{ag}}=0.33 \times\left[\mathrm{NO}_{2}\right]$ (Groblicki et al., 1981). Here, $\mathrm{NO}_{2}$ was in units of $\times 10^{-9} \mathrm{~V} / \mathrm{V}$. Rayleigh scattering coefficient $\left(\sigma_{\mathrm{sg}}\right)$ was assumed to be a constant of $0.013 \mathrm{~km}^{-1}$ at sea level (Chan et al., 1999; Peundorf, 1957). The scattering coefficient of light due to moisture in the air $\left(b_{\mathrm{sw}}\right)$ could be neglected when relatively humidity (RH) was lower than $70 \%$ (Cass, 1979; Chan et al., 1999). In this study, the average relative humidity was about $60 \%$. Consequently, the total light extinction by particles and gases $\left(\sigma_{\mathrm{ext}}=\sigma_{\mathrm{ep}}+\sigma_{\mathrm{ag}}+\sigma_{\mathrm{sg}}\right)$ was calculated and the visibility could be estimated.

\section{Supplementary material related to this article is available online at: http://www.atmos-chem-phys.net/12/105/2012/ acp-12-105-2012-supplement.pdf.}

Acknowledgements. Many thanks to the MODIS, OMI and AIRS data processing team members. We thank Sugimoto Nobuo and Shimizu Atsushi of National Institute for Environmental Studies, Japan, for the lidar setup and data inversion. This work was supported by the great international collaboration project of MOST, China (2010DFA92230), National Natural Science Foundation of China (Grant Nos. 41128005 (fund for collaboration with oversea scholars), 20877020, 20977017), and Shanghai environmental protection science developing funding (No. 2010-003, 2011-55).

Edited by: T. Wang

\section{References}

Amato, F., Pandolfi, M., Viana, M., Querol, X., Alastuey, A., and Moreno, T.: Spatial and chemical patterns of $\mathrm{PM}_{10}$ in road dust deposited in urban environment, Atmos. Environ., 43, 16501659, 2009.

Andreae, M. O.: Soot Carbon and Excess Fine Potassium - LongRange Transport of Combustion-Derived Aerosols, Science, 220, 4602, 1148-1151, 1983.

Andreae, M. O. and Merlet, P.: Emission of trace gases and aerosols from biomass burning, Global Biogeochem. Cy., 15, 955-966, 2001.

Andreae, M. O., Schmid, O., Yang, H., Chand, D., Yu, J. Z., Zeng, L. M., and Zhang, Y. H.: Optical properties and chemical composition of the atmospheric aerosol in urban Guangzhou, China, Atmos. Environ., 42, 6335-6350, 2008.

Arimoto, R., Duce, R. A., Savoie, D. L., Prospero, J. M., Talbot, R., Cullen, J. D., Tomza, U., Lewis, N. F., and Jay, B. J.: Relationships among aerosol constituents from Asia and the North Pacific during PEM-West A, J. Geophys. Res., 101, 2011-2023, 1996.

Boian, C. and Kirchhoff, V. W. J. H.: Measurements of CO in an aircraft experiment and their correlation with biomass burning and air mass origin in South America, Atmos. Environ., 38, 63376347, 2004.

Brammer, H. and Ravenscroft, P.: Arsenic in groundwater: A threat to sustainable agriculture in South and South-East Asia, Environ. Int., 35, 647-654, 2009.

Cai, H. and Xie, S. D.: Estimation of vehicular emission inventories in China from 1980 to 2005, Atmos. Environ., 41, 8963-8979, 2007.

Cao, T., An, L., Wang, M., Lou, Y. X., Yu, Y. H., Wu, J. M., Zhu, Z. R., Qing, Y. K., and Glime, J.: Spatial and temporal changes of heavy metal concentrations in mosses and its indication to the environments in the past $40 \mathrm{yr}$ in the city of Shanghai, China, Atmos. Environ., 42, 5390-5402, 2008.

Cass, G. R.: On the relationship between sulfate air quality and visibility with examples in los angeles, Atmos. Environ., 13, 10691084, 1979.

Chakrabarty, R. K., Moosmuller, H., Garro, M. A., Arnott, W. P., Walker, J., Susott, R. A., Babbitt, R. E., Wold, C. E., Lincoln, E. N., and Hao, W. M.: Emissions from the laboratory combustion of wildland fuels: Particle morphology and size, J. Geophys. Res., 111, D07204, doi:10.1029/2005JD006659, 2006.

Chan, C. K., and Yao, X.: Air pollution in mega cities in China, Atmos. Environ., 42, 1-42, 2008.

Chan, Y. C., Simpson, R. W., McTainsh, G. H., Vowles, P. D., Cohen, D. D., and Bailey, G. M.: Source apportionment of visibility degradation problems in Brisbane (Australia) using the multiple linear regression techniques, Atmos. Environ., 33, 3237-3250, 1999.

Chang, D. and Song, Y.: Estimates of biomass burning emissions in tropical Asia based on satellite-derived data, Atmos. Chem. Phys., 10, 2335-2351, doi:10.5194/acp-10-2335-2010, 2010. 
Chang, D., Song, Y., and Liu, B.: Visibility trends in six megacities in China 1973-2007, Atmos. Res., 94, 161-167, 2009.

Che, H. Z., Shi, G. Y., Zhang, X. Y., Arimoto, R., Zhao, J. Q., $\mathrm{Xu}$, L., Wang, B., and Chen, Z. H.: Analysis of $40 \mathrm{yr}$ of solar radiation data from China, 1961-2000, Geophys. Res. Lett., 32, L06803, doi:10.1029/2004GL022322, 2005.

Che, H. Z., Zhang, X. Y., Li, Y., Zhou, Z. J., and Qu, J. J.: Horizontal visibility trends in China 1981-2005, Geophys. Res. Lett., 34, L24706, doi:10.1029/2007GL031450, 2007.

Chen, C. H., Wang, B. Y., Fu, Q. Y., Green, C., and Streets, D. G.: Reductions in emissions of local air pollutants and co-benefits of Chinese energy policy: a Shanghai case study, Energ. Policy, 34, 754-762, 2006.

Chen, J. M., Tan, M. G., Li, Y. L., Zhang, Y. M., Lu, W. W., Tong, Y. P., Zhang, G. L., and Li, Y.: A lead isotope record of shanghai atmospheric lead emissions in total suspended particles during the period of phasing out of leaded gasoline, Atmos. Environ., 39, 1245-1253, 2005.

Choi, S. D. and Chang, Y. S.: Carbon monoxide monitoring in Northeast Asia using MOPITT: Effects of biomass burning and regional pollution in April 2000, Atmos. Environ., 40, 686-697, 2006.

Chow, J. C. and Watson, J. G.: $\mathrm{PM}_{2.5}$ carbonate concentrations at regionally representative Interagency Monitoring of Protected Visual Environment sites, J. Geophys. Res., 107, 8344 doi:10.1029/2001JD000574, 2002.

Chu, D. A., Kaufman, Y. J., Zibordi, G., Chern, J. D., Mao, J., Li, C. C., and Holben, B. N.: Global monitoring of air pollution over land from the Earth Observing System-Terra Moderate Resolution Imaging Spectroradiometer (MODIS), J. Geophys. Res., 108, 4661, doi:10.1029/2002JD003179, 2003.

Deng, C., Zhuang, G., Huang, K., Li, J., Zhang, R., Wang, Q., Liu, T., Sun, Y., Guo, Z., Fu, J. S., and Wang, Z.: Chemical characterization of aerosols at the summit of Mountain Tai in Central East China, Atmos. Chem. Phys., 11, 7319-7332, doi:10.5194/acp11-7319-2011, 2011.

Fang, M., Chan, C. K., and Yao, X. H.: Managing air quality in a rapidly developing nation: China, Atmos. Environ., 43, 79-86, 2009.

Feng, J. L., Hu, M., Chan, C. K., Lau, P. S., Fang, M., He, L. Y., and Tang, X. Y.: A comparative study of the organic matter in $\mathrm{PM}_{2.5}$ from three Chinese megacities in three different climatic zones, Atmos. Environ., 40, 3983-3994, 2006.

Feng, Y. L., Chen, Y. J., Guo, H., Zhi, G. R., Xiong, S. C., Li, J., Sheng, G. Y., and Fu, J. M.: Characteristics of organic and elemental carbon in $\mathrm{PM}_{2.5}$ samples in Shanghai, China, Atmos. Res., 92, 434-442, 2009.

Fernald, F. G.: Analysis of Atmospheric Lidar Observations - Some Comments, Appl. Opt., 23, 652-653, 1984.

Fu, Q. Y., Zhuang, G. S., Wang, J., Xu, C., Huang, K., Li, J., Hou, B., Lu, T., and Streets, D. G.: Mechanism of formation of the heaviest pollution episode ever recorded in the Yangtze River Delta, China, Atmos. Environ., 42, 2023-2036, 2008.

Gao, J., Wang, T., Zhou, X. H., Wu, W. S., and Wang, W. X.: Measurement of aerosol number size distributions in the Yangtze River delta in China: Formation and growth of particles under polluted conditions, Atmos. Environ., 43, 829-836, 2009.

Garland, R. M., Yang, H., Schmid, O., Rose, D., Nowak, A., Achtert, P., Wiedensohler, A., Takegawa, N., Kita, K., Miyazaki,
Y., Kondo, Y., Hu, M., Shao, M., Zeng, L. M., Zhang, Y. H., Andreae, M. O., and Pöschl, U.: Aerosol optical properties in a rural environment near the mega-city Guangzhou, China: implications for regional air pollution, radiative forcing and remote sensing, Atmos. Chem. Phys., 8, 5161-5186, doi:10.5194/acp-85161-2008, 2008.

Geng, F. H., Zhang, Q., Tie, X. X., Huang, M. Y., Ma, X. C., Deng, Z. Z., Yu, Q., Quan, J. N., and Zhao, C. S.: Aircraft measurements of $\mathrm{O}_{3}, \mathrm{NO}_{\mathrm{x}}, \mathrm{CO}$, VOCs, and $\mathrm{SO}_{2}$ in the Yangtze River Delta region, Atmos. Environ., 43, 584-593, 2009.

Giglio, L.: Characterization of the tropical diurnal fire cycle using VIRS and MODIS observations, Remote Sens. Environ., 108, 407-421, 2007.

Groblicki, P. J., Wolff, G. T., and Countess, R. J.: VisibilityReducing Species in the Denver Brown Cloud 1, Relationships between Extinction and Chemical-Composition, Atmos. Environ., 15, 2473-2484, 1981.

Hasan, H. and Dzubay, T. G.: Apportioning Light Extinction Coefficients to Chemical-Species in Atmospheric Aerosol, Atmos. Environ., 17, 1573-1581, 1983.

He, Y., Uno, I., Wang, Z., Ohara, T., Sugirnoto, N., Shimizu, A., Richter, A., and Burrows, J. P.: Variations of the increasing trend of tropospheric $\mathrm{NO}_{2}$ over central east China during the past decade, Atmos. Environ., 41, 4865-4876, 2007.

Huang, K., Zhuang, G. S., Xu, C., Wang, Y., and Tang, A. H.: The chemistry of the severe acidic precipitation in Shanghai, China, Atmos. Res., 89, 149-160, 2008.

Huang, K., Zhuang, G. S., Li, J. A., Wang, Q. Z., Sun, Y. L., Lin, Y. F., and Fu, J. S.: Mixing of Asian dust with pollution aerosol and the transformation of aerosol components during the dust storm over China in spring 2007, J. Geophys. Res., 115, D00K13, doi:10.1029/2009JD013145, 2010.

Kaiser, D. P. and Qian, Y.: Decreasing trends in sunshine duration over China for 1954-1998: Indication of increased haze pollution?, Geophys. Res. Lett., 29, 2042, doi:10.1029/2002GL016057, 2002.

Kan, H. D. and Chen, B. H.: Particulate air pollution in urban areas of Shanghai, China: health-based economic assessment, Sci. Total Environ., 322, 71-79, 2004.

Kan, H. D., London, S. J., Chen, G. H., Zhang, Y. H., Song, G. X., Zhao, N. Q., Jiang, L. L., and Chen, B. H.: Differentiating the effects of fine and coarse particles on daily mortality in Shanghai, China, Environ. Int., 33, 376-384, 2007.

Kato, S., Akimoto, H., Rockmann, T., Braunlich, M., and Brenninkmeijer, C. A. M.: Stable isotopic compositions of carbon monoxide from biomass burning experiments, Atmos. Environ. 33, 4357-4362, 1999.

Kato, S., Pochanart, P., Hlrokawa, J., Kajii, Y., Akimoto, H., Ozaki, Y., Obi, K., Katsuno, T., Streets, D. G., and Minko, N. P.: The influence of Siberian forest fires on carbon monoxide concentrations at Happo, Japan, Atmos. Environ., 36, 385-390, 2002.

Kaufman, Y. J., Wald, A. E., Remer, L. A., Gao, B. C., Li, R. R., and Flynn, L.: The MODIS $2.1 \mu \mathrm{m}$ channel - Correlation with visible reflectance for use in remote sensing of aerosol, IEEE T. Geosci. Remote, 35, 1286-1298, 1997.

Kim, S. W., Yoon, S. C., Kim, J., Kang, J. Y., and Sugimoto, N.: Asian dust event observed in Seoul, Korea, during 29-31 May 2008: Analysis of transport and vertical distribution of dust particles from lidar and surface measurements, Sci. Total Environ. 
408, 1707-1718, 2010.

Kurosu, T. P., Chance, K., and Sioris, C. E.: Preliminary Results for $\mathrm{HCHO}$ and $\mathrm{BrO}$ from the EOS-Aura Ozone Monitoring Instrument, Proc. of SPIE in: Passive Optical Remote Sensing of the Atmosphere and Clouds IV, edited by: Tsay, S. C., Yokota, T., and Ahn, M.-H., 5652, 2004.

Lee, S., Ghim, Y. S., Kim, S. W., and Yoon, S. C.: Seasonal characteristics of chemically apportioned aerosol optical properties at Seoul and Gosan, Korea, Atmos. Environ., 43, 1320-1328, 2009.

Levelt, P. F., Van den Oord, G. H. J., Dobber, M. R., Malkki, A., Visser, H., de Vries, J., Stammes, P., Lundell, J. O. V., and Saari, H.: The Ozone Monitoring Instrument, IEEE T. Geosci. Remote, 44, 1093-1101, 2006.

Levy, R. C., Remer, L. A., Kleidman, R. G., Mattoo, S., Ichoku, C., Kahn, R., and Eck, T. F.: Global evaluation of the Collection 5 MODIS dark-target aerosol products over land, Atmos. Chem. Phys., 10, 10399-10420, doi:10.5194/acp-10-10399-2010, 2010.

Li, C., Zhang, Q., Krotkov, N. A., Streets, D. G., He, K. B., Tsay, S. C., and Gleason, J. F.: Recent large reduction in sulfur dioxide emissions from Chinese power plants observed by the Ozone Monitoring Instrument, Geophys. Res. Lett., 37, L08807, doi:10.1029/2010GL042594, 2010.

Li, J., Posfai, M., Hobbs, P. V., and Buseck, P. R.: Individual aerosol particles from biomass burning in southern Africa - Part 2: Compositions and aging of inorganic particles, J. Geophys. Res., 108, 8484 doi:10.1029/2002JD002310, 2003.

Li, P. F., Li, X., Yang, C. Y., Wang, X. J., Chen, J. M., and Collett, J. L.: Fog water chemistry in Shanghai, Atmos. Environ., 45, 4034-4041, 2011.

Li, X. G., Wang, S. X., Duan, L., Hao, J., Li, C., Chen, Y. S., and Yang, L.: Particulate and trace gas emissions from open burning of wheat straw and corn stover in China, Environ. Sci. Technol., 41, 6052-6058, 2007.

Li, Z. Q., Chen, H., Cribb, M., Dickerson, R., Holben, B., Li, C., Lu, D., Luo, Y., Maring, H., Shi, G., Tsay, S. C., Wang, P., Wang, Y., Xia, X., Zheng, Y., Yuan, T., and Zhao, F.: Preface to special section on East Asian studies of tropospheric aerosols: An international regional experiment (EAST-AIRE), J. Geophys. Res., 112, D22S00, doi:10.1029/2007JD008853, 2007.

Liu, F., Wang, X. K., and Zhu, Y. G.: Assessing current and future ozone-induced yield reductions for rice and winter wheat in Chongqing and the Yangtze River Delta of China, Environ. Pollut., 157, 707-709, 2009.

Liu, Z., Liu, D., Huang, J., Vaughan, M., Uno, I., Sugimoto, N., Kittaka, C., Trepte, C., Wang, Z., Hostetler, C., and Winker, D.: Airborne dust distributions over the Tibetan Plateau and surrounding areas derived from the first year of CALIPSO lidar observations, Atmos. Chem. Phys., 8, 5045-5060, doi:10.5194/acp-85045-2008, 2008.

Liu, Z. Y., Sugimoto, N., and Murayama, T.: Extinction-tobackscatter ratio of Asian dust observed with high-spectralresolution lidar and Raman lidar, Appl. Opt., 41, 2760-2767, 2002.

Lu, Z., Streets, D. G., Zhang, Q., Wang, S., Carmichael, G. R., Cheng, Y. F., Wei, C., Chin, M., Diehl, T., and Tan, Q.: Sulfur dioxide emissions in China and sulfur trends in East Asia since 2000, Atmos. Chem. Phys., 10, 6311-6331, doi:10.5194/acp-106311-2010, 2010.

Malm, W. C., Sisler, J. F., Huffman, D., Eldred, R. A., and Cahill,
T. A.: Spatial and Seasonal Trends in Particle Concentration and Optical Extinction in the United-States, J. Geophys. Res.Atmos., 99, 1347-1370, 1994.

Mandal, B. K. and Suzuki, K. T.: Arsenic round the world: a review, Talanta, 58, 201-235, 2002.

Mari, C. H., Cailley, G., Corre, L., Saunois, M., Attié, J. L., Thouret, V., and Stohl, A.: Tracing biomass burning plumes from the Southern Hemisphere during the AMMA 2006 wet season experiment, Atmos. Chem. Phys., 8, 3951-3961, doi:10.5194/acp-8-3951-2008, 2008.

McMillan, W. W., Barnet, C., Strow, L., Chahine, M. T., McCourt, M. L., Warner, J. X., Novelli, P. C., Korontzi, S., Maddy, E. S., and Datta, S.: Daily global maps of carbon monoxide from NASA's Atmospheric Infrared Sounder, Geophys. Res. Lett., 32, L11801, doi:10.1029/2004GL021821, 2005.

Mcneil, W. R. and Carswell, A. I.: Lidar Polarization Studies of Troposphere, Appl. Opt., 14, 2158-2168, 1975.

Noh, Y. M., Kim, Y. J., Choi, B. C., and Murayama, T.: Aerosol lidar ratio characteristics measured by a multi-wavelength Raman lidar system at Anmyeon Island, Korea, Atmos. Res., 86, 76-87, 2007.

Nriagu, J. O.: A Global Assessment of Natural Sources of Atmospheric Trace-Metals, Nature, 338, 6210, 47-49, 1989.

Ouimette, J. R. and Flagan, R. C.: The Extinction Coefficient of Multicomponent Aerosols, Atmos. Environ., 16, 2405-2419, 1982.

Pan, L. A., Che, H. Z., Geng, F. H., Xia, X. G., Wang, Y. Q., Zhu, C. Z., Chen, M., Gao, W., and Guo, J. P.: Aerosol optical properties based on ground measurements over the Chinese Yangtze Delta Region, Atmos. Environ., 44, 2587-2596, 2010.

Parrish, D. D. and Zhu, T.: Clean Air for Megacities, Science, 326, 674-675, 5953, doi:10.1126/science.1176064, 2009.

Pathak, R. K., Wu, W. S., and Wang, T.: Summertime $\mathrm{PM}_{2.5}$ ionic species in four major cities of China: nitrate formation in an ammonia-deficient atmosphere, Atmos. Chem. Phys., 9, 17111722, doi:10.5194/acp-9-1711-2009, 2009.

Paton-Walsh, C., Jones, N., Wilson, S., Meier, A., Deutscher, N., Griffith, D., Mitchell, R., and Campbell, S.: Trace gas emissions from biomass burning inferred from aerosol optical depth, Geophys. Res. Lett., 31, L05116, doi:10.1029/2003GL018973, 2004.

Peundorf, R.: Tables of the refractive index for standard and the Rayleigh scattering coefficient for the spectral region between 0.2 and 20.0 microns and their application to atmospheric optics, J. Opt. Soc. Am., 47, 176-182, 1957.

Shi, G. T., Chen, Z. L., Xu, S. Y., Zhang, J., Wang, L., Bi, C. J., and Teng, J. Y.: Potentially toxic metal contamination of urban soils and roadside dust in Shanghai, China, Environ. Pollut., 156, 251-260, 2008.

Shimizu, A., Sugimoto, N., Matsui, I., Arao, K., Uno, I., Murayama, T., Kagawa, N., Aoki, K., Uchiyama, A., and Yamazaki, A.: Continuous observations of Asian dust and other aerosols by polarization lidars in China and Japan during ACE-Asia, J. Geophys. Res., 109, D19S17, doi:10.1029/2002JD003253, 2004.

SMSB: Shanghai Municipal Statistics Bureau, Shanghai sixth national census in 2010 Communiqué on Major Data, 2011, (in Chinese).

Sugimoto, N., Matsui, I., Shimizu, A., Uno, I., Asai, K., Endoh, T., and Nakajima, T.: Observation of dust and anthropogenic aerosol plumes in the Northwest Pacific with a two-wavelength polariza- 
tion lidar on board the research vessel Mirai, Geophys. Res. Lett., 29, 1901, doi:10.1029/2002GL015112, 2002.

Sun, Y., Zhang, Q., Macdonald, A. M., Hayden, K., Li, S. M., Liggio, J., Liu, P. S. K., Anlauf, K. G., Leaitch, W. R., Steffen, A., Cubison, M., Worsnop, D. R., van Donkelaar, A., and Martin, R. V.: Size-resolved aerosol chemistry on Whistler Mountain, Canada with a high-resolution aerosol mass spectrometer during INTEX-B, Atmos. Chem. Phys., 9, 3095-3111, doi:10.5194/acp9-3095-2009, 2009.

Sun, Y. L., Zhuang, G. S., Ying, W., Han, L. H., Guo, J. H., Mo, D., Zhang, W. J., Wang, Z. F., and Hao, Z. P.: The air-borne particulate pollution in Beijing - concentration, composition, distribution and sources, Atmos. Environ., 38, 5991-6004, 2004.

Tan, M. G., Zhang, G. L., Li, X. L., Zhang, Y. X., Yue, W. S., Chen, J. M., Wang, Y. S., Li, A. G., Li, Y., Zhang, Y. M., and Shan, Z. C.: Comprehensive study of lead pollution in Shanghai by multiple techniques, Anal. Chem., 78, 8044-8050, 2006.

Tie, X. X., Geng, F. H., Peng, L., Gao, W., and Zhao, C. S.: Measurement and modeling of $\mathrm{O}_{3}$ variability in Shanghai, China: Application of the WRF-Chem model, Atmos. Environ., 43, 4289-4302, 2009.

Turpin, B. J. and Lim, H. J.: Species contributions to $\mathrm{PM}_{2.5}$ mass concentrations: Revisiting common assumptions for estimating organic mass, Aerosol Sci. Technol., 35, 602-610, 2001.

US Environmental Protection Agency (EPA): Quality assurance handbook for air pollution measurement systems, EPA454/R98004, Research Triangle Park, NC, US, 1998.

van der A, R. J., Peters, D. H. M. U., Eskes, H., Boersma, K. F., Van Roozendael, M., De Smedt, I., and Kelder, H. M.: Detection of the trend and seasonal variation in tropospheric $\mathrm{NO}_{2}$ over China, J. Geophys. Res., 111, D12317, doi:10.1029/2005JD006594, 2006.

Xia, X. G., Li, Z. Q., Holben, B., Wang, P., Eck, T., Chen, H. B., Cribb, M., and Zhao, Y. X.: Aerosol optical properties and radiative effects in the Yangtze Delta region of China, J. Geophys. Res., 112, D22S12, doi:10.1029/2007JD008859, 2007.

Xu, J., Bergin, M. H., Yu, X., Liu, G., Zhao, J., Carrico, C. M., and Baumann, K.: Measurement of aerosol chemical, physical and radiative properties in the Yangtze delta region of China, Atmos. Environ., 36, 161-173, 2002.

Yamaji, K., Li, J., Uno, I., Kanaya, Y., Irie, H., Takigawa, M., Komazaki, Y., Pochanart, P., Liu, Y., Tanimoto, H., Ohara, T., Yan, X., Wang, Z., and Akimoto, H.: Impact of open crop residual burning on air quality over Central Eastern China during the Mount Tai Experiment 2006 (MTX2006), Atmos. Chem. Phys., 10, 7353-7368, doi:10.5194/acp-10-7353-2010, 2010.

Yan, X. Y., Ohara, T., and Akimoto, H.: Bottom-up estimate of biomass burning in mainland China, Atmos. Environ., 40, 52625273, 2006.

Yang, F., He, K., Ye, B., Chen, X., Cha, L., Cadle, S. H., Chan, T., and Mulawa, P. A.: One-year record of organic and elemental carbon in fine particles in downtown Beijing and Shanghai, Atmos. Chem. Phys., 5, 1449-1457, doi:10.5194/acp-5-1449-2005, 2005a.

Yang, F. M., Ye, B. M., He, K. B., Ma, Y. L., Cadle, S. H., Chan, T., and Mulawa, P. A.: Characterization of atmospheric mineral components of $\mathrm{PM}_{2.5}$ in Beijing and Shanghai, China, Sci. Total Environ., 343, 221-230, 2005b.

Yao, X. H., Chan, C. K., Fang, M., Cadle, S., Chan, T., Mulawa, P.,
He, K. B., and Ye, B. M.: The water-soluble ionic composition of $\mathrm{PM}_{2.5}$ in Shanghai and Beijing, China, Atmos. Environ., 36, 4223-4234, 2002.

Ye, B. M., Ji, X. L., Yang, H. Z., Yao, X. H., Chan, C. K., Cadle, S. H., Chan, T., and Mulawa, P. A.: Concentration and chemical composition of $\mathrm{PM}_{2.5}$ in Shanghai for a $1 \mathrm{yr}$ period, Atmos. Environ., 37, 499-510, 2003.

Ye, S. H., Zhou, W., Song, J., Peng, B. C., Yuan, D., Lu, Y. M., and Qi, P. P.: Toxicity and health effects of vehicle emissions in Shanghai, Atmos. Environ., 34, 419-429, 2000.

Yuan, H., Wang, Y., and Zhuang, G. S.: Simultaneous determination of organic acids, methanesulfonic acid and inorganic anions in aerosol and precipitation samples by ion chromatography, Journal of Instrumental Analysis, 22, 11-44, 2003.

Wang, H. X., Tang, X. Y., Wang, M. L., Yan, P., Wang, T., Shao, K. S., Zeng, L. M., Du, H. F., and Chen, L. M.: Characteristics of observed trace gaseous pollutants in the Yangtze Delta, Sci. China. Ser. D., 46, 397-404, 2003.

Wang, K. C., Dickinson, R. E., and Liang, S. L.: Clear Sky Visibility Has Decreased over Land Globally from 1973 to 2007, Science, 323, 1468-1470, 2009.

Wang, T., Cheung, T. F., Li, Y. S., Yu, X. M., and Blake, D. R.: Emission characteristics of $\mathrm{CO}, \mathrm{NO}_{\mathrm{X}}, \mathrm{SO}_{2}$ and indications of biomass burning observed at a rural site in Eastern China, J. Geophys. Res., 107, 4157, doi:10.1029/2001JD000724, 2002.

Wang, T., Nie, W., Gao, J., Xue, L. K., Gao, X. M., Wang, X. F., Qiu, J., Poon, C. N., Meinardi, S., Blake, D., Wang, S. L., Ding, A. J., Chai, F. H., Zhang, Q. Z., and Wang, W. X.: Air quality during the 2008 Beijing Olympics: secondary pollutants and regional impact, Atmos. Chem. Phys., 10, 7603-7615, doi:10.5194/acp-10-7603-2010, 2010.

Wang, Y., Zhuang, G. S., Tang, A. H., Zhang, W. J., Sun, Y. L., Wang, Z. F., and An, Z. S.: The evolution of chemical components of aerosols at five monitoring sites of China during dust storms, Atmos. Environ., 41, 1091-1106, 2007.

Wang, Y., Zhuang, G. S., Zhang, X. Y., Huang, K., Xu, C., Tang, A. H., Chen, J. M., and An, Z. S.: The ion chemistry, seasonal cycle, and sources of $\mathrm{PM}_{2.5}$ and TSP aerosol in Shanghai, Atmos. Environ., 40, 2935-2952, 2006.

Zhang, H. F., Ye, X. N., Cheng, T. T., Chen, J. M., Yang, X., Wang, L., and Zhang, R. Y.: A laboratory study of agricultural crop residue combustion in China: Emission factors and emission inventory, Atmos. Environ., 42, 8432-8441, 2008.

Zhang, Q., Streets, D. G., Carmichael, G. R., He, K. B., Huo, H., Kannari, A., Klimont, Z., Park, I. S., Reddy, S., Fu, J. S., Chen, D., Duan, L., Lei, Y., Wang, L. T., and Yao, Z. L.: Asian emissions in 2006 for the NASA INTEX-B mission, Atmos. Chem. Phys., 9, 5131-5153, doi:10.5194/acp-9-5131-2009, 2009.

Zhang, W. J., Zhuang, G. S., Huang, K., Li, J. A., Zhang, R., Wang, Q. Z., Sun, Y. L., Fu, J. S., Chen, Y., Xu, D. Q., and Wang, W.: Mixing and transformation of Asian dust with pollution in the two dust storms over the northern China in 2006, Atmos. Environ., 44, 3394-3403, 2010.

Zhang, X. Y., Zhuang, G. Y., Zhu, G. H., Zhang, D., An, Z. S., Chen, T., and Huang, X. P.: Element tracers for Chinese source dust, Sci. China Ser. D, 39, 512-521, 1996.

Zhang, X. Y., Gong, S. L., Shen, Z. X., Mei, F. M., Xi, X. X., Liu, L. C., Zhou, Z. J., Wang, D., Wang, Y. Q., and Cheng, Y.: Characterization of soil dust aerosol in China and its transport and 
distribution during 2001 ACE-Asia: 1. Network observations, J. Geophys. Res.-Atmos., 108, 4261, doi:10.1029/2002JD002632, 2003.

Zhang, X. Y., Zhang, P., Zhang, Y., Li, X. J., and Qiu, H.: The trend, seasonal cycle, and sources of tropospheric $\mathrm{NO}_{2}$ over China during 1997-2006 based on satellite measurement, Sci. China. Ser. D., 50, 1877-1884, 2007.

Zhang, X. Y., Wang, Y. Q., Zhang, X. C., Guo, W., and Gong, S. L.: Carbonaceous aerosol composition over various regions of China during 2006, J. Geophys. Res., 113, D14111, doi:10.1029/2007JD009525, 2008.

Zhang, Y. H., Hu, M., Zhong, L. J., Wiedensohler, A., Liu, S. C., Andreae, M. O., Wang, W., and Fan, S. J.: Regional Integrated Experiments on Air Quality over Pearl River Delta 2004 (PRIDE-PRD2004): Overview, Atmos. Environ., 42, 61576173, 2008.

Zhang, Y. P., Wang, X. F., Chen, H., Yang, X., Chen, J. M., and Allen, J. O.: Source apportionment of lead-containing aerosol particles in Shanghai using single particle mass spectrometry, Chemosphere, 74, 501-507, 2009.
Zhao, X. S., Wan, Z., Zhu, H. G., and Chen, R. P.: The carcinogenic potential of extractable organic matter from urban airborne particles in Shanghai, China, Mutat. Res.-Gen. Tox. En., 540, 107-117, 2003.

Zhou, X. H., Cao, J., Wang, T., Wu, W. S., and Wang, W. X.: Measurement of black carbon aerosols near two Chinese megacities and the implications for improving emission inventories, Atmos. Environ., 43, 3918-3924, 2009.

Zhou, Y., Fu, J. S., Zhuang, G. S., and Levy, J. I.: Risk-Based Prioritization among Air Pollution Control Strategies in the Yangtze River Delta, China, Environ. Health Perspect., 118, 1204-1210, 2010.

Zhuang, G. S., Guo, J. H., Yuan, H., and Zhao, C. Y.: The compositions, sources, and size distribution of the dust storm from China in spring of 2000 and its impact on the global environment, Chinese Sci. Bull., 46, 89-901, 2001. 